WSRC-TR-2003-00135, Rev. 0

SRT-RPP-2003-00045

\title{
Cesium Eluate Semi-Batch Evaporation Performance
}

March 2003

Westinghouse Savannah River Company

Savannah River Site

Aiken, SC 29808

Prepared for the U.S. Department of Energy Under Contract Number DEAC09-96SR18500

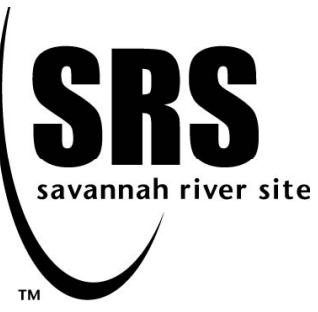


This document was prepared in conjunction with work accomplished under Contract No. DE-AC09-96SR18500 with the U. S. Department of Energy.

\section{DISCLAIMER}

This report was prepared as an account of work sponsored by an agency of the United States Government. Neither the United States Government nor any agency thereof, nor any of their employees, makes any warranty, express or implied, or assumes any legal liability or responsibility for the accuracy, completeness, or usefulness of any information, apparatus, product or process disclosed, or represents that its use would not infringe privately owned rights. Reference herein to any specific commercial product, process or service by trade name, trademark, manufacturer, or otherwise does not necessarily constitute or imply its endorsement, recommendation, or favoring by the United States Government or any agency thereof. The views and opinions of authors expressed herein do not necessarily state or reflect those of the United States Government or any agency thereof.

This report has been reproduced directly from the best available copy.

Available for sale to the public, in paper, from: U.S. Department of Commerce, National Technical Information Service, 5285 Port Royal Road, Springfield, VA 22161, phone: (800) 553-6847, fax: (703) 605-6900

email: orders@ntis.fedworld.gov

online ordering: http://www.ntis.gov/help/index.asp

Available electronically at http://www.osti.gov/bridge

Available for a processing fee to U.S. Department of Energy and its contractors, in paper, from: U.S. Department of Energy, Office of Scientific and Technical Information, P.O. Box 62, Oak Ridge, TN 37831-0062,

phone: (865)576-8401,

fax: (865)576-5728

email: $\underline{\text { reports@ adonis.osti.gov }}$ 
WSRC-TR-2003-00135, Rev. 0

SRT-RPP-2003-00045

KEYWORDS:

River Protection Project Laboratory Cesium Eluate

Evaporation Solubility

Physical Properties

RETENTION TIME:

0.1.1.1.1 Permanent

\section{Cesium Eluate Semi-Batch Evaporation Performance}

Authors:

Issue Date:

Test Specification No.

Test Plan No.

Test Scoping Statement:
Robert A. Pierce, 773-A, SRTC, SRS

March 2003

24590-WTP-TSP-RT-01-009, Rev. 0

WSRC-TR-2001-00508, Rev. 0

S-78

Westinghouse Savannah River Company Savannah River Site Aiken, SC 29808

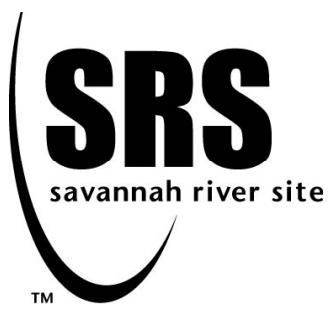


WSRC-TR-2003-00135, Rev. 0

SRT-RPP-2003-00045

Completeness of Testing

This report describes the results of work and testing specified by 24590-WTPTSP-RT-01-009, Rev. 0 and WSRC-TR-2001-00508, Rev. 0.. The performed work followed established quality assurance requirements and was conducted as authorized. The descriptions provided in this test report are an accurate account of both the conduct of the work and the data collected. Results required by the test plan are reported. Also reported are any unusual or anomalous occurrences that are different from starting hypotheses. The test results and this report have been reviewed and verified. 


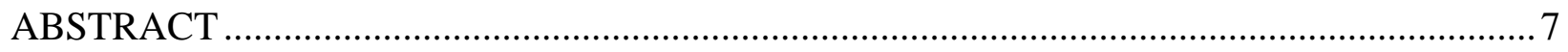

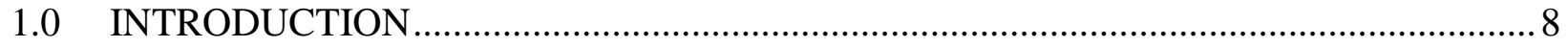

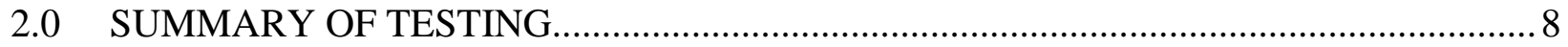

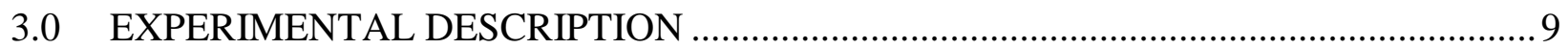

3.1 CESIUM ELUATE SIMULANT PREPARATION …………………………………............

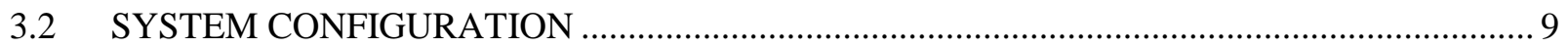

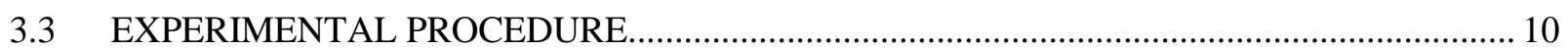

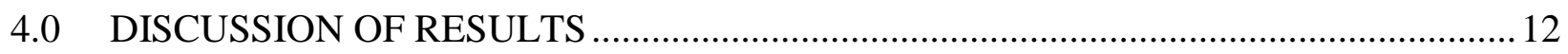

$4.1 \quad$ EVAPORATION PROFILES - HIGH-ACID TESTS …………………………………….... 12

4.2 EVAPORATION PROFILES - MODERATE- AND LOW-ACID TESTS .................................15

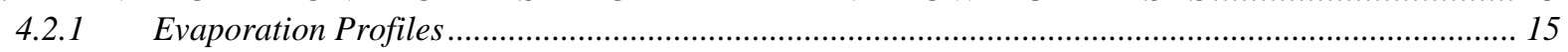

4.2.2 AN-102 Condensate Data ……………………………………………………………………... 16

4.3 PHYSICAL PROPERTIES - EVAPORATOR CONCENTRATE ……………………………. 17

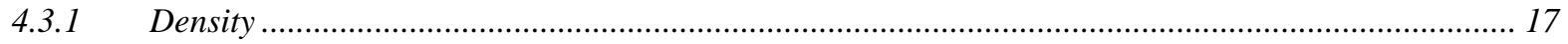

4.3.2 Viscosity and Heat Capacity ................................................................................................... 20

5.0 RECOMMENDED SIMULANT FOR PLANT COMMISSIONING.............................222

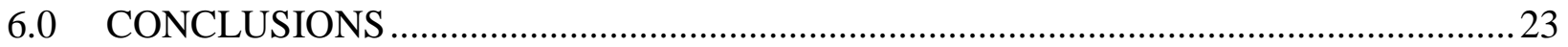

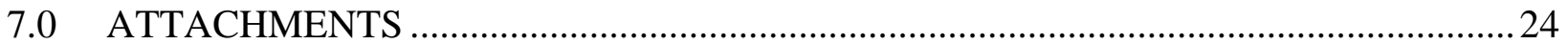




\section{LIST OF FIGURES}

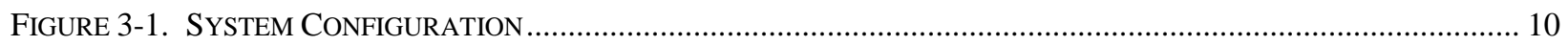

FIGURE 3-2. EVAPORATION EQUIPMENT IN CHEMICAL HOOD ........................................................................... 11

Figure 4-1. MATRIX BeHAVIOR DURING CS ElUATE SEMI-BATCH EVAPORATION ……........................................... 14

FIGURE 4-2. MATRIX CONCENTRATION AS A FUNCTION OF EVAPORATION......................................................... 14

FiguRE 4-3. AN-102 Cs ElUATE SEMI-BATCH EVAPORATION BEHAVIOR ................................................................ 17

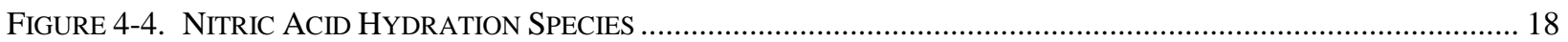

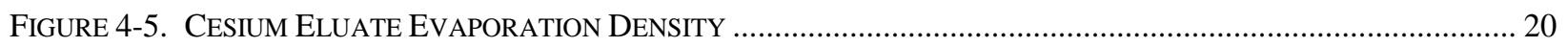

FIGURE 4-6. CESIUM ElUATE EVAPORATION VISCOSITY ................................................................................... 21

\section{LIST OF TABLES}

TABle 3-1. Cesium Eluate Simulant Batch SheEt ....................................................................................... 9

TABLE 3-2. SAMPLES REMOVED FROM THE EVAPORATOR POT, HIGH-ACID TESTS ……........................................ 12

TABLE 4-1. $\mathrm{NANO}_{3}-\mathrm{HNO}_{3}$ EVAPORATION DATA, 7.5M HNO 3 TESTS .......................................................... 13

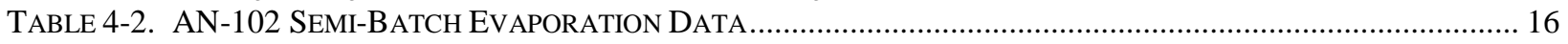

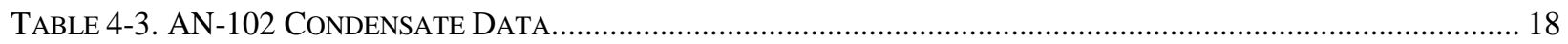

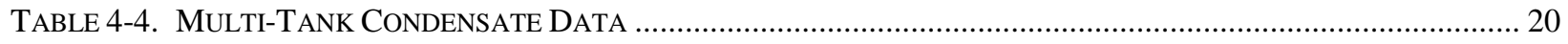

TABLE 4-5. SUMMARY OF EXPERIMENTAL DENSITY DATA ............................................................................. 20

TABLE 4-6. PhYSICAL PROPERTY DATA COMPARISONS ..................................................................................... 21

\section{ATTACHMENTS}

ATTACHMENT 1. COMPARISON OF EleCtrical CONDUCTIVITY DATA FOR NITRIC ACID ....................................... 24

ATTACHMENT 2. BATCH SHEET FOR PLANT-COMMISSIONING SIMULANT ................................................................. 25

\section{LIST OF ACRONYMS}

$\begin{array}{ll}\text { LAW } & \text { Low Activity Waste } \\ \text { NIST } & \text { National Institute of Standards and Technology } \\ \text { PNNL } & \text { Pacific Northwest National Laboratory } \\ \text { RPP } & \text { River Protection Project } \\ \text { SRTC } & \text { Savannah River Technology Center } \\ \text { TFL } & \text { Thermal Fluids Laboratory } \\ \text { WTP } & \text { Waste Treatment Plant } \\ \text { XRD } & \text { X-ray Diffraction }\end{array}$




\title{
WSRC-TR-2003- 00135, Rev. 0 \\ SRT-RPP-2003-00045
}

\begin{abstract}
The baseline flowsheet for low activity waste (LAW) in the Hanford River Protection Project (RPP) Waste Treatment Plant (WTP) includes pretreatment of supernatant by removing cesium using ion exchange. When the ion exchange column is loaded, the cesium will be eluted with a $0.5 \mathrm{M}$ nitric acid $\left(\mathrm{HNO}_{3}\right)$ solution to allow the column to be conditioned for re-use. The cesium eluate solution will then be concentrated in a vacuum evaporator to minimize storage volume and to recycle $\mathrm{HNO}_{3}$.
\end{abstract}

SRTC formulated four cesium eluate simulant solutions for use in a bench-scale evaporation experiment. SRTC researchers initially designed the bench scale evaporation unit to evaporate the simulated eluate from Pilot Scale Ion Exchange Testing. The cesium eluate simulants created reflect the best available data for cesium eluate from Tanks AN-102, AN-103, AN-107 and AW-101. Data from the AZ-102 experiments have been evaluated in conjunction with these more recent tests.

Of the five simulant compositions tested with the same starting acid concentration (7.5-7.6M), four evaporation profiles (AZ-102, AN-102, AN-107 and AW-101) are quite similar. These four evaporation profiles cross the $\mathrm{NaNO}_{3}-\mathrm{HNO}_{3}$ solubility curve at essentially the same point. The similarity of behavior is noteworthy considering the significant differences between the different test matrices in both salt and acid concentrations. The fifth matrix (AN-103) behaves similar to the others until the end. The divergence of AN-103 may be attributable to the high calcium-to-sodium ratio in the feed.

It was also observed that evaporator pot acidity does not always change linearly during the evaporation. All five tests show linear depletion of nitric acid in the evaporator pot from the start of the test until 5.0-5.5M total acid. Afterwards, the total acid concentration remains relatively constant even though more feed is being continuously added and dilute acid is continuously removed.

When the starting acid concentration in the evaporator pot was reduced while running the AN-102 simulant, the evaporation profile changed. Contrary to earlier tests, total acidity in the evaporator pot increased at the outset when the starting pot acidity was $4.0 \mathrm{M}$ and $5.25 \mathrm{M}$. Even though the feed was nominally $0.28 \mathrm{M}$ acid and the pot acidity was much higher, the initial condensate coming from the evaporator had less acidity than the feed. The trend of the pot acidity eventually turns to one where the acid in the evaporator pot decreases with time. It was also observed that both the $4.0 \mathrm{M}$ and $5.25 \mathrm{M} \mathrm{HNO}_{3}$ tests under vacuum demonstrate a tendency to concentrate to a lower total acid (4.3-4.4M) before precipitation occurs. While no definitive explanation for the observed behavior has been discovered, it is speculated that the waters of hydration associated with nitric acid may play a role.

The result from the atmospheric pressure at 5.25M starting acid lends some support to this theory. The only difference between the two moderate-acid tests is that one occurs at 70 torr, with a boiling point of about $55^{\circ} \mathrm{C}$, while the other occurs at about 760 torr, with a boiling point of about $108^{\circ} \mathrm{C}$. The test at atmospheric pressure does not show the sharp increase in acidity. Rather, its acidity decreases steadily until it plateaus at $3.5 \mathrm{M} \mathrm{HNO}$. The primary difference with respect to the two liquids is boiling temperature. It can be reasonably postulated that the energy in the atmospheric pressure system (boiling point $=108^{\circ} \mathrm{C}$ ) is sufficient to overcome the transition between two different nitric acid hydration species and avoid concentrating. The energy at 70 torr (boiling point $=55^{\circ} \mathrm{C}$ ) is insufficient to completely overcome the transition between two different nitric acid hydration species.

In addition to solubility data, physical property data was also collected. The physical properties measured included density, viscosity, and heat capacity.

The testing of individual cesium eluate simulants in a semi-batch manner is the precursor to recommending a cesium eluate simulant for plant commissioning. Although there are many candidate compositions, from actual tank data to experimental formulations, the preferred candidate should be a simulant of an actual tank composition. Such a selection will increase confidence in the likelihood of success during plant commissioning. In addition, the selected simulant should be a composition that 1) is well-characterized, 2) has been evaluated experimentally, 3) is easy to simulate, and 4) has the potential to precipitate cesium under adverse conditions. Of the compositions evaluated, the AZ-102 matrix presents itself as the preferred matrix for plant commissioning. 


\section{WSRC-TR-2003- 00135, Rev. 0 \\ SRT-RPP-2003-00045}

\subsection{INTRODUCTION}

The baseline flowsheet for low activity waste (LAW) in the Hanford River Protection Project (RPP) Waste Treatment Plant (WTP) includes pretreatment of supernatant by removing cesium using ion exchange. When the ion exchange column is loaded, the cesium will be eluted off the resin with a $0.5 \mathrm{M}$ nitric acid $\left(\mathrm{HNO}_{3}\right)$ solution to allow the column to be conditioned for re-use. The cesium eluate solution will then be concentrated in a vacuum evaporator to minimize storage volume and recycle $\mathrm{HNO}_{3}$. To prevent the formation of solids during storage of the evaporator bottoms, criteria have been set for limiting the concentration of the evaporator product to $80 \%$ of saturation at $25^{\circ} \mathrm{C}$.

Prior work has collected fundamental data for predicting solubility and other physical properties. ${ }^{1}$ Other ongoing efforts have involved the development of a computer model to predict solubility and physical properties during evaporation. ${ }^{2}$ Evaporation experiments were conducted with four cesium eluate simulants at the Savannah River Technology Center (SRTC). The tests supplement earlier work with an AZ-102 cesium eluate simulant. ${ }^{3}$ The data from the experiments will be used to validate the model predictions and recommend a cesium eluate composition for plant commissioning.

This report completes the activities of Section 3.2 of the Task Technical and Quality Assurance Plan (TTQAP) for Evaluating the Evaporation Behavior of Cs Eluate (WSRC-TR-2001-00508). Section 3.4 of the TTQAP addresses Cs eluate evaporation experiments using simulants. The TTQAP specifically states the specific QA requirements governing this task in accordance with applicable requirements of NQA-1-1989 and NQA-2, 1990, Part 2.7.

\subsection{SUMMARY OF TESTING}

SRTC researchers initially designed the bench scale evaporation unit to evaporate the simulated eluate from Pilot Scale Ion Exchange Testing, however, solutions were not available in time to satisfy the schedule for this work. Therefore, SRTC formulated four cesium eluate simulant solutions for use in a bench-scale evaporation study. The cesium eluate simulants created reflect the best available data for cesium eluate from Tanks AN-102, AN-103, AN107 and AW-101.

The laboratory-scale evaporator was configured for semi-continuous operation and offgas collection under vacuum conditions. A conductivity meter was used in conjunction with the experiment for correlation with overhead condensate nitric acid concentrations. It should be noted that the bench scale unit did not include a reflux column, or rectifier, because the overheads can be withdrawn at the appropriate concentration without a rectifier.

Testing included the following activities:

1. Predict Evaporator Behavior: The data collected from previous experiments was used to predict the evaporator behavior. The information in the OLI Systems Inc. (OLI) evaporation model was also used to predict the evaporator behavior for the simulant.

2. Perform Evaporator Experiments: Four experiments were performed with the simulants formulated by SRTC to represent the best available cesium eluate data for Tanks AN-102, AN-103, AN-107 and AW-101. The experimental evaporator was operated at constant volume with the capability to periodically removing liquid samples. Eluate feed rate to the evaporator was controlled to match the condensate volume in a near-continuous

\footnotetext{
${ }^{1}$ R. A. Pierce and T. B. Edwards, "Cesium Eluate Evaporation Solubility and Physical Property Behavior," WSRCTR-2002-00273, dated June 11, 2002.

${ }^{2}$ A. S. Choi, T. B. Edwards, and R. A. Pierce, "Physical Property Models of Concentrated Cesium Eluate Solutions," WSRC-TR-2002-00424, dated March 4, 2003.

${ }^{3}$ R. A. Pierce and A. S. Choi, "Cesium Eluate Evaporation Solubility and Physical Property Behavior," WSRC-TR2002-00411, dated September 9, 2002.
} 


\section{WSRC-TR-2003- 00135, Rev. 0}

SRT-RPP-2003-00045

manner. The experimental procedure is comparable to the method used for testing an AZ-102 simulant generated in the Thermal Fluids Laboratory (TFL) pilot unit. ${ }^{3}$

3. Analyze Process Samples: The bulk solubility at $25+0 /-5{ }^{\circ} \mathrm{C}$ for each simulant was estimated using concentration factors and batch information. Some starting, intermediate and final samples from the evaporator pot were analyzed for heat capacity, liquid density, viscosity, and total acid (titration). Condensate acidity was measured using a conductivity probe.

\subsection{EXPERIMENTAL DESCRIPTION}

\subsection{CESIUM ELUATE SIMULANT PREPARATION}

Four cesium eluate simulant solutions were prepared based on the best available experimental data from SRTC and PNNL. ${ }^{4}$ Calculations were performed and batch sheets were created (Table 3-1). Salts were weighed on a calibrated balance. Nitric acid volumes were measured using a graduated cylinder whose markings had been validated with weighed deionized water. The final volume for each simulant was obtained by diluting with deionized water. Visual inspection of the final solutions confirmed that all solids had dissolved.

Table 3-1. Cesium Eluate Simulant Batch Sheet

\begin{tabular}{|c|c|c|c|c|c|}
\hline Simulant & AN-103 & AN-102 & AW-101 & AN-107 & $\begin{array}{c}\text { TFL } \\
\text { AZ-102* }\end{array}$ \\
\hline \multicolumn{6}{|l|}{ Nitrate Salt } \\
\hline $\mathrm{CsNO}_{3}(\mathrm{~g})$ & 3.710 & 0.598 & 2.822 & 0.194 & ---- \\
\hline $\mathrm{KNO}_{3}(\mathrm{~g})$ & 4.096 & 3.517 & 25.681 & 1.365 & $\begin{array}{ll}--- \\
\end{array}$ \\
\hline $\mathrm{NaNO}_{3}(\mathrm{~g})$ & 86.172 & 92.972 & 214.249 & 86.335 & $\begin{array}{ll}--- \\
\end{array}$ \\
\hline $\mathrm{Al}\left(\mathrm{NO}_{3}\right)_{3}-9 \mathrm{H}_{2} \mathrm{O}(\mathrm{g})$ & 18.034 & 63.300 & 50.934 & 1.375 & $\begin{array}{ll}--- \\
\end{array}$ \\
\hline $\mathrm{Ni}\left(\mathrm{NO}_{3}\right)_{2}-6 \mathrm{H}_{2} \mathrm{O}(\mathrm{g})$ & 0.000 & 0.379 & 0.386 & 11.117 & ---- \\
\hline $\mathrm{Ca}\left(\mathrm{NO}_{3}\right)_{2}-4 \mathrm{H}_{2} \mathrm{O}(\mathrm{g})$ & 37.572 & 6.607 & 0.306 & 0.000 & ---- \\
\hline $\mathrm{Cu}\left(\mathrm{NO}_{3}\right)_{2}-2.5 \mathrm{H}_{2} \mathrm{O}(\mathrm{g})$ & 0.645 & 1.868 & $4.857 \mid$ & 1.813 & ---- \\
\hline $\mathrm{Fe}\left(\mathrm{NO}_{3}\right)_{3}-9 \mathrm{H}_{2} \mathrm{O}(\mathrm{g})$ & 4.475 & 2.182 & 2.966 & 2.220 & ---- \\
\hline $\mathrm{Mg}\left(\mathrm{NO}_{3}\right)_{2}-6 \mathrm{H}_{2} \mathrm{O}(\mathrm{g})$ & 3.018 & 1.614 & 0.000 & 0.000 & ---- \\
\hline $\mathrm{Zn}\left(\mathrm{NO}_{3}\right)_{2}-6 \mathrm{H}_{2} \mathrm{O}(\mathrm{g})$ & 2.101 & 0.309 & 1.606 & 0.379 & ---- \\
\hline $\begin{array}{l}\text { Anhydrous Salt Concentration } \\
(\mathrm{g} / \mathrm{L})\end{array}$ & 6.21 & 8.34 & 21.45 & 2.99 & 5.98 \\
\hline $15.7 \mathrm{M} \mathrm{HNO} \mathrm{HN}_{3}(\mathrm{~mL})$ & 334.2 & 300.1 & 239.4 & 754.9 & $\begin{array}{c}--- \\
\end{array}$ \\
\hline $\mathrm{HNO}_{3}(\mathrm{M})$ & 0.24 & 0.28 & 0.29 & 0.36 & 0.52 \\
\hline Final Volume (liters) & 22.0 & 17.0 & 13.0 & 33.0 & $-\overline{---}$ \\
\hline
\end{tabular}

*Denotes earlier experiment for comparison in the discussion of results

\subsection{SYSTEM CONFIGURATION}

A schematic of the experimental setup is included in Figure 3-1. A picture of the evaporation and two condensers is shown in Figure 3-2. The evaporator, feed reservoir, mist eliminator, and condensers were fabricated in the SRTC Glass Shop. The evaporator is a 5-inch diameter glass vessel with a volume of $2200 \mathrm{~mL}$. Heating is supplied through a Fisher Scientific IR4100 infrared hot plate. The evaporator is wrapped with an insulation blanket and has glass beads in the bottom to act as boiling stones. Feed is drawn into the evaporator by the vacuum in the system and is regulated through a metering stopcock. The evaporator temperature is monitored using a Cole-Parmer Type $\mathbf{J}$ thermocouple and thermocouple readout. The evaporator pressure is measured using a calibrated Omega Engineering PX01C1-O20AI high-accuracy pressure transducer attached to an Omega DP41-E meter. The evaporator top is also equipped with an air bleed valve to control evaporator pressure.

\footnotetext{
${ }^{4}$ R. A. Pierce, “Cesium Eluate Analytical Data Evaluation.” WSRC-TR-2001-00594 (January 2002).
} 


\section{WSRC-TR-2003- 00135, Rev. 0 \\ SRT-RPP-2003-00045}

Condenser \#1 is a 4-inch diameter vessel that is approximately 19 inches tall. Cooling coils extend 12 inches down into the vessel. The liquid volume below the coils is $1200 \mathrm{~mL}$ and the volume below the gas inlet tube is $1400 \mathrm{~mL}$. Condenser \#1 is cooled using a Neslab RTE-211 chiller. Condensate is removed from the system using a Fluid Metering, Inc. Model QV Pump.

Condenser \#2 is a 4-inch diameter vessel that is approximately 14.5 inches tall. Cooling coils extend 13.5 inches down into the vessel. The liquid volume below the coils is $150 \mathrm{~mL}$ and the volume below the gas inlet tube is 300 $\mathrm{mL}$. Condenser \#2 is cooled using a Lauda E200 chiller. Condensate is removed from the system using a Fluid Metering, Inc. Model QV Pump.

Vacuum is pulled on the system using a Vacuubrand MZ 2C Pump. Condensate conductivity is measured using a YSI 3200 Conductivity Meter equipped with a YSI Type 3253 Glass Dip Cell. Titrations performed in the lab use certified $0.0050-0.010 \mathrm{M} \mathrm{NaOH}$ with endpoint determined using phenolphthalein indicator.

Figure 3-1. System Configuration

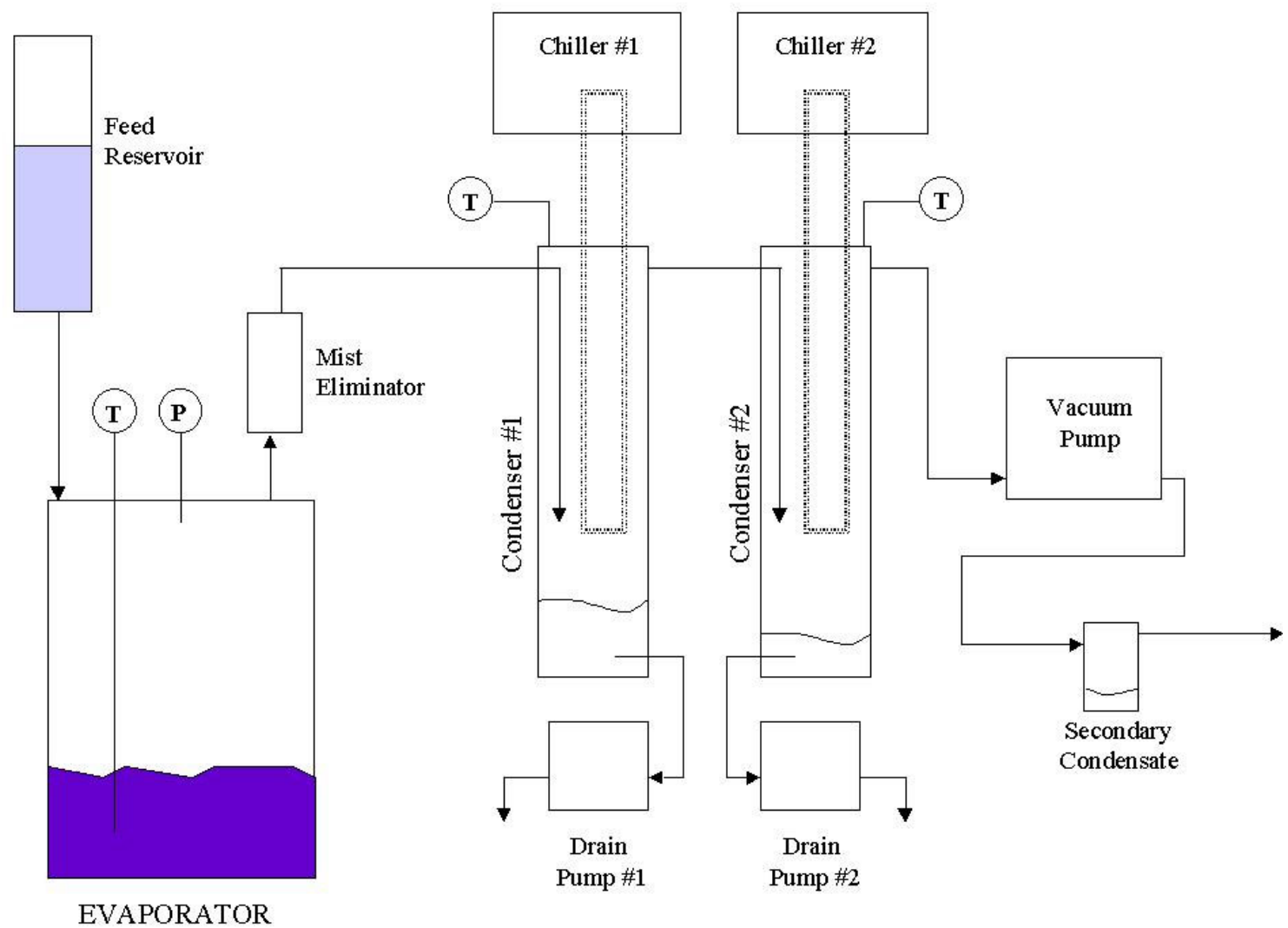

\subsection{EXPERIMENTAL PROCEDURE}

The evaporation tests were all run in a similar manner. The evaporator pressure was 70+/-3 torr. For the first four tests, the starting pot volume was $250 \mathrm{~mL}$ of $7.5 \mathrm{M} \mathrm{HNO}_{3}$. Two subsequent tests started with $250 \mathrm{~mL}$ of $4.0 \mathrm{M}$ and $5.25 \mathrm{M} \mathrm{HNO}_{3}$, respectively. A seventh experiment (run at atmospheric pressure) used a smaller evaporator pot with $50 \mathrm{~mL}$ of $5.25 \mathrm{M} \mathrm{HNO}_{3}$ at the start. The evaporator pot was marked with a line to indicate the initial operating volume. As samples were withdrawn, the line was moved to reflect the adjusted volume. The first chiller was set at $20^{\circ} \mathrm{C}$ and the second chiller operated at $5-10^{\circ} \mathrm{C}$. The chillers are operated at temperatures below the RPP design values in order to minimize the amount of condensate lost from the system so that the measured condensate acidity 


\section{WSRC-TR-2003- 00135, Rev. 0 \\ SRT-RPP-2003-00045}

closely reflects the composition of what was evaporated. The other primary controls were the evaporator pot and feed volumes. Temperatures in the evaporator pot and two condensers were monitored with thermocouples.

The test was performed at a rate of approximately 16-20 evaporator volumes per day - eight in the morning and eight to twelve in the afternoon. After each set of four evaporator volumes, the vacuum was removed from the system and the condensers were emptied. Any liquid in the mist eliminator was charged back into the evaporator. During the test, samples were periodically removed to analyze for density $(10 \mathrm{~mL})$ and total acid by titration $(0.10$ $0.15 \mathrm{~mL}$ ). Because of vigorous boiling in the evaporator pot, the total acid value varies (as much as $\pm 10 \%$ ) due to difficulty in maintaining absolute constant volume. The density sample is not consumed in the analysis and, therefore, is returned to the evaporator pot. There were no foaming problems encountered during evaporation.

Figure 3-2. Evaporation Equipment in Chemical Hood

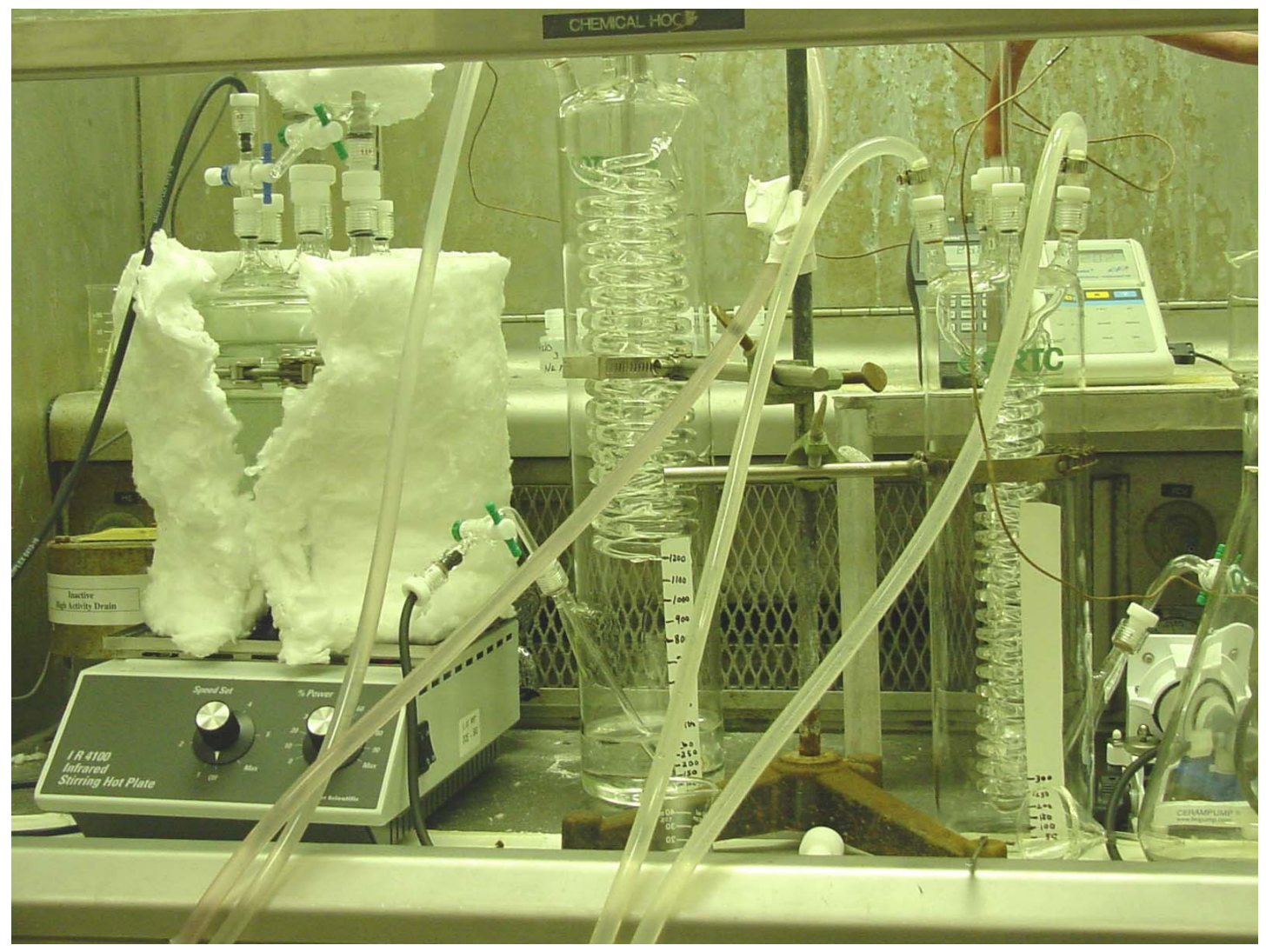

A conductivity probe measured evaporator condensate acidity. The conductivity probe was checked against three known $\mathrm{HNO}_{3}$ solutions $-0.262 \mathrm{M}, 0.524 \mathrm{M}$, and $0.774 \mathrm{M}$ - prior to analysis of condensate samples. A comparison of calibration data with literature data is contained in Attachment 1 . The condensate from Condensers \#1 and \#2 were combined prior to analysis. The condensate for the morning portion of the test was analyzed for conductivity and stored. At the end of the afternoon portion of the test, the condensate was once again analyzed and stored. Secondary condensate from each day was also collected and titrated for acid.

At the appropriate time, as saturation was approached, samples were removed and stored to look for precipitation. These occurred at different times due to the significant differences in salt concentrations between the various simulants (see Table 3-1). Table 3-2 lists the samples that were withdrawn during the tests with $7.5 \mathrm{M}$ acid in the pot at the beginning. Tests using $4.0 \mathrm{M}$ and $5.25 \mathrm{M} \mathrm{HNO}_{3}$ at the start did not withdraw intermediate samples because the primary objective of the tests was to measure the change in total acidity throughout the test. When samples were removed, the feed and pot control volumes were adjusted to compensate for the withdrawn sample. Upon cooling, these samples were inspected for solids. The evaporation sequence was continued until precipitation was observed 


\section{WSRC-TR-2003- 00135, Rev. 0 \\ SRT-RPP-2003-00045}

in the evaporator pot sample that had cooled to room temperature. It is important to note that during the low-acid test (4.0M starting acid), when 48 pot volumes had been added to the system, that pot volume was accidentally evaporated to below the mark. Approximately $24 \mathrm{~mL}$ of condensate had to be added back to the pot to bring it up to the control line in the hope that the liquid addition would offset the unintended volume and acid loss. It is unclear how this would affect the final pot acidity for that test.

All intermediate samples were analyzed for density at $20^{\circ} \mathrm{C}$ using an Anton-Paar DMA 4500 density meter. The density meter is accurate to $0.0001 \mathrm{~g} / \mathrm{cm}^{3}$. Prior to analyzing samples, the instrument calibration is verified using deionized water. The samples are injected into the instrument, the instrument adjusts the sample temperature to $20^{\circ} \mathrm{C}$, and the sample is analyzed. Intermediate samples were also analyzed for total acid (by titration), heat capacity

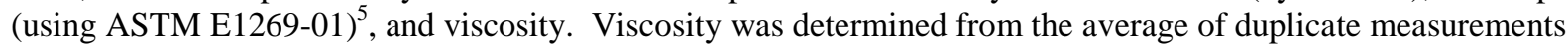
using calibrated Cannon-Fenske Size 50 viscometers (sized for approximate viscosity of 1-5 cp). Following precipitation in the evaporator pot, the solids from the $7.5 \mathrm{M} \mathrm{HNO}_{3}$ tests were filtered at room temperature and analyzed using x-ray diffraction (XRD). The liquids from the 7.5 $\mathrm{M} \mathrm{HNO}_{3}$ tests were analyzed for density, viscosity, heat capacity, and total acid. Primary and secondary condensate samples were analyzed for acid concentration using conductivity.

Table 3-2. Samples Removed from the Evaporator Pot, High-Acid Tests

\begin{tabular}{|l|c|c|c|c|}
\hline Simulant & AN-102 & AN-103 & AN-107 & AW-101 \\
\hline Sample 1 & 44 volumes* & 60 volumes* & 82 volumes & 12 volumes \\
\hline Sample 2 & 48 volumes* & 64 volumes* & 86 volumes & 14 volumes \\
\hline Sample 3 & --- & --- & 90 volumes* & 16 volumes* \\
\hline Sample 4 & --- & --- & 94 volumes* & --- \\
\hline
\end{tabular}

\subsection{DISCUSSION OF RESULTS}

\subsection{EVAPORATION PROFILES - HIGH-ACID TESTS}

The exact point of precipitation is difficult to determine immediately because the solutions are heated to $55^{\circ} \mathrm{C}$ and then cooled to room temperature. Therefore they can become supersaturated, relative to room temperature, before they will precipitate. The best way to identify the approximate solubility point is to withdraw intermediate samples as the solubility point is approached and allow the samples sufficient time to precipitate. Since the primary component in all four tests is $\mathrm{NaNO}_{3}$, the end point for each experiment is estimated using $\mathrm{NaNO}_{3}-\mathrm{HNO}_{3}$ solubility data. ${ }^{6}$ The $\mathrm{NaNO}_{3}$ concentration at any point in the experiment is calculated based on the known starting $\mathrm{NaNO}_{3}$ concentration, the known volume of feed added to the evaporator, and control of the evaporator liquid volume. The $\mathrm{HNO}_{3}$ concentration is measured using acid-base titration. Because of vigorous boiling in the evaporator pot, the total acid value can vary as much as $\pm 10 \%$ due to difficulty in maintaining constant volume, although $\pm 5 \%$ is more likely. The resulting $\mathrm{NaNO}_{3}$ and $\mathrm{HNO}_{3}$ concentrations are then plotted on a diagram containing the $\mathrm{NaNO}_{3}-\mathrm{HNO}_{3}$ solubility data.

The $\mathrm{NaNO}_{3}-\mathrm{HNO}_{3}$ data for the four tests is presented in Table 4-1. The acid concentration values in the are measured values using titration; sodium concentration data is calculated based on starting volume and total volumes of feed evaporated. Because the system contains only nitrate salts, $\mathrm{NaNO}_{3}$ is represented in the Table as $\mathrm{Na}^{+}$and $\mathrm{HNO}_{3}$ is represented as $\mathrm{H}^{+}$. The cells containing data with a gray background and bold text are those samples in which a precipitant was observed. It is important to note that, although there are no long-term samples from the AN-102 and AN-103 compositions without precipitates, the precipitates that formed in the AN-102 and AN-103

\footnotetext{
${ }^{5}$ E1269-01 - Standard Test Method for Determining Specific Heat Capacity by Differential Scanning Calorimetry. ASTM International (West Conshohocken, PA), Copyright 2002.

${ }^{6}$ R. A. Pierce and T. B. Edwards, "Cesium Eluate Evaporation Solubility and Physical Property Behavior," WSRCTR-2002-00273, dated June 11, 2002.
} 


\section{WSRC-TR-2003- 00135, Rev. 0 \\ SRT-RPP-2003-00045}

compositions did so after extended storage. Experience indicates that if earlier samples had been gathered they would not have produced a precipitant (e.g. AN-107 at 86 volumes and AW-101 at 14 volumes).

The data of Table 4-1 has been plotted along with the experimental solubility curve for sodium nitrate. ${ }^{5}$ (Figure 4-1). Figure 4-1 also contains data from the semi-batch evaporation test using AZ-102 Cs eluate simulant from the SRTC TFL (Thermal Fluids Lab) pilot-scale test. ${ }^{7}$ All of the red open symbols of Figure 4-1 represent data points where precipitation occurred.

Three things stand out in Figure 4-1. The first is that four of the five evaporation profiles (AZ-102, AN-102, AN107 and AW-101) are quite similar. Four of the five evaporation profiles cross the $\mathrm{NaNO}_{3}-\mathrm{HNO}_{3}$ solubility curve at essentially the same point. Even the evaporation profile of the fifth matrix (AN-103) is similar to the others until the end. The divergence of AN-103 is likely due to the high Ca-to-Na ratio in the feed (see Table 3-1). The behavior is quite surprising considering the significant differences between the different test matrices in both salt and acid concentrations (see Table 3-1). Figure 4-2 shows the difference between the matrices in how they concentrate at much different rates and still end up at essentially the same end point.

The second important observation of Figure 4-1 is that for the four similar matrices, precipitation occurs only in those samples that are above the $\mathrm{NaNO}_{3}-\mathrm{HNO}_{3}$ solubility curve and not in those below the curve. Therefore, in those matrices where sodium nitrate is the dominant component, overall system saturation is accurately predicted using the $\mathrm{NaNO}_{3}-\mathrm{HNO}_{3}$ solubility profile. The behavior of the $\mathrm{AN}-103$ matrix shows that a high level of calcium can cause sodium nitrate to precipitate before the predicted point represented in the $\mathrm{NaNO}_{3}-\mathrm{HNO}_{3}$ solubility profile.

The third noteworthy observation is that evaporator pot acidity does not always change linearly during the evaporation. The expectation at the start of the tests is that acid would be gradually depleted in a more or less linear fashion until saturation was achieved or until the pot acidity approached the feed matrix acidity. All five tests show the expected linear depletion of nitric acid in the evaporator pot from the start of the test until 5.0-5.5M total acid. Afterwards, the total acid concentration remains relatively constant even though more feed is being continuously added and dilute acid is continuously removed.

Table 4-1. $\mathrm{NaNO}_{3}-\mathrm{HNO}_{3}$ Evaporation Data, $7.5 \mathrm{M} \mathrm{HNO} 3$ Tests

\begin{tabular}{|c|c|c|c|c|c|c|c|c|c|c|c|}
\hline \multicolumn{3}{|c|}{ AW-101 } & \multicolumn{3}{|c|}{ AN-102 } & \multicolumn{3}{|c|}{ AN-103 } & \multicolumn{3}{|c|}{ AN-107 } \\
\hline$\overline{C F}$ & $\mathrm{H}+(\mathrm{M})$ & $\mathrm{Na}+(\mathrm{M})$ & $\mathrm{CF}$ & $\mathrm{H}+(\mathrm{M})$ & $\mathrm{Na}+(\mathrm{M})$ & $\mathrm{CF}$ & $\mathrm{H}+(\mathrm{M})$ & $\mathrm{Na}+(\mathrm{M})$ & CF & $\mathrm{H}+(\mathrm{M})$ & $\mathrm{Na}+(\mathrm{M})$ \\
\hline 0 & 7.62 & 0.00 & 0 & 7.54 & 0.00 & 0 & 7.64 & 0.00 & 0 & 7.64 & 0.00 \\
\hline 4 & 6.82 & 0.77 & 4 & 7.06 & 0.26 & 12 & 6.61 & 0.55 & 10 & 7.00 & 0.31 \\
\hline 8 & 6.29 & 1.55 & 8 & 6.34 & 0.51 & 28 & 5.65 & 1.29 & 22 & 6.48 & 0.68 \\
\hline 12 & 5.59 & 2.32 & 12 & 6.09 & 0.77 & 40 & 4.94 & 1.84 & 30 & 6.76 & 0.92 \\
\hline 14 & 5.21 & 2.71 & 16 & 6.01 & 1.03 & 48 & 4.42 & 2.21 & 42 & 6.20 & 1.29 \\
\hline $\mathrm{A}_{16}$ & 5.37 & 3.10 & 20 & 5.77 & 1.29 & 52 & 4.58 & 2.40 & 52 & 5.48 & 1.60 \\
\hline & & & 24 & 5.85 & 1.54 & 56 & 4.46 & 2.58 & 64 & 5.17 & 1.97 \\
\hline & & & 28 & 5.45 & 1.80 & ${ }^{6} 60$ & 4.46 & 2.77 & 74 & 5.13 & 2.28 \\
\hline & & & 32 & 5.21 & 2.06 & 64 & 4.54 & 2.95 & 82 & 5.37 & 2.52 \\
\hline & & & 36 & 4.97 & 2.32 & & & & 86 & 5.17 & 2.65 \\
\hline & & & 40 & 4.97 & 2.57 & & & & Do & 5.56 & 2.77 \\
\hline & & & ${ }^{B} 44$ & 5.13 & 2.83 & & & & 94 & 5.92 & 2.89 \\
\hline & & & 48 & 5.05 & 3.09 & & & & & & \\
\hline - & & & 11 & & & & & & & & \\
\hline
\end{tabular}

${ }^{7}$ R. A. Pierce and A. S. Choi, "Cesium Eluate Evaporation Solubility and Physical Property Behavior," WSRC-TR2002-00411, dated September 9, 2002. 
Figure 4-1. Matrix Behavior during Cs Eluate Semi-Batch Evaporation

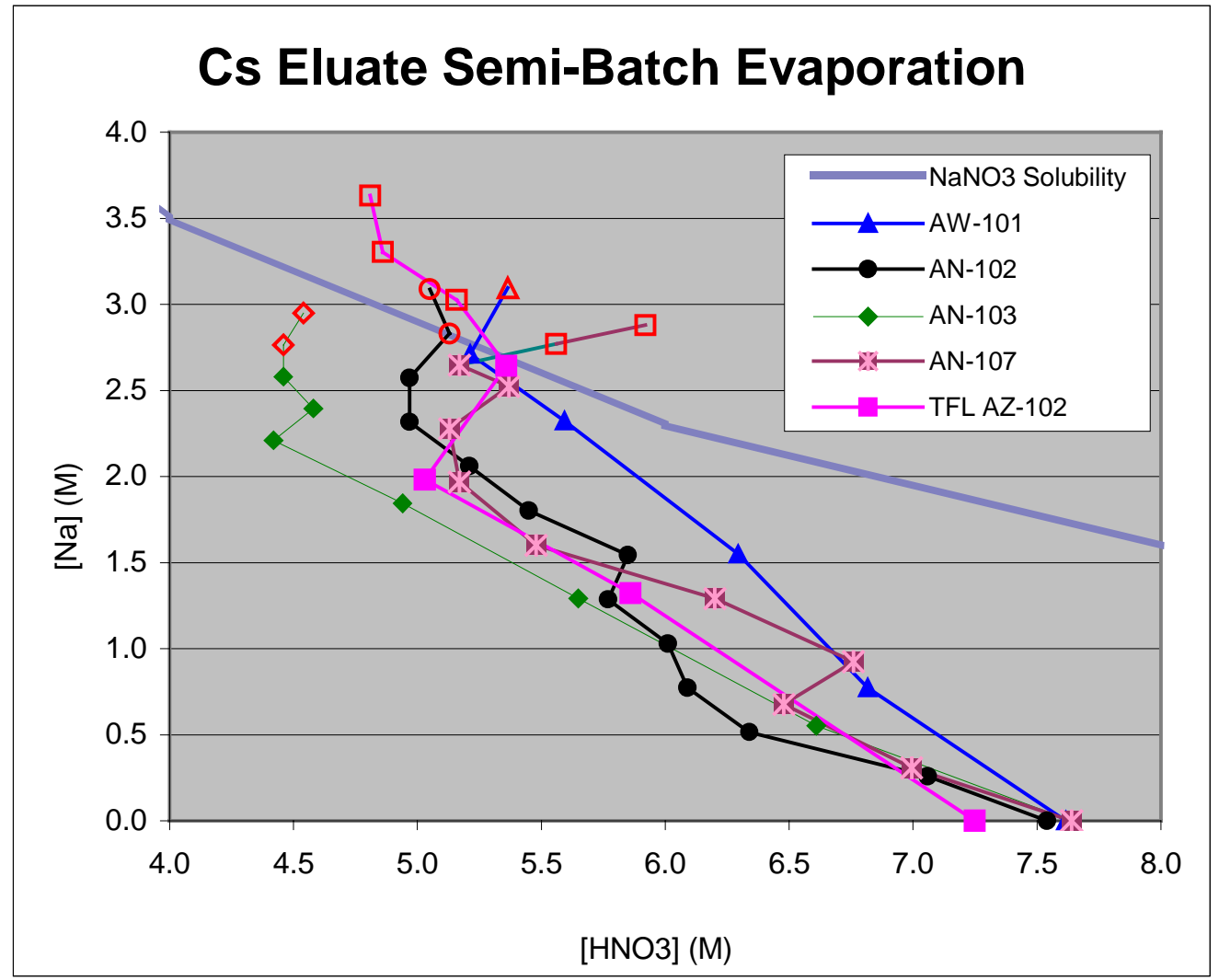

Figure 4-2. Matrix Concentration as a Function of Evaporation

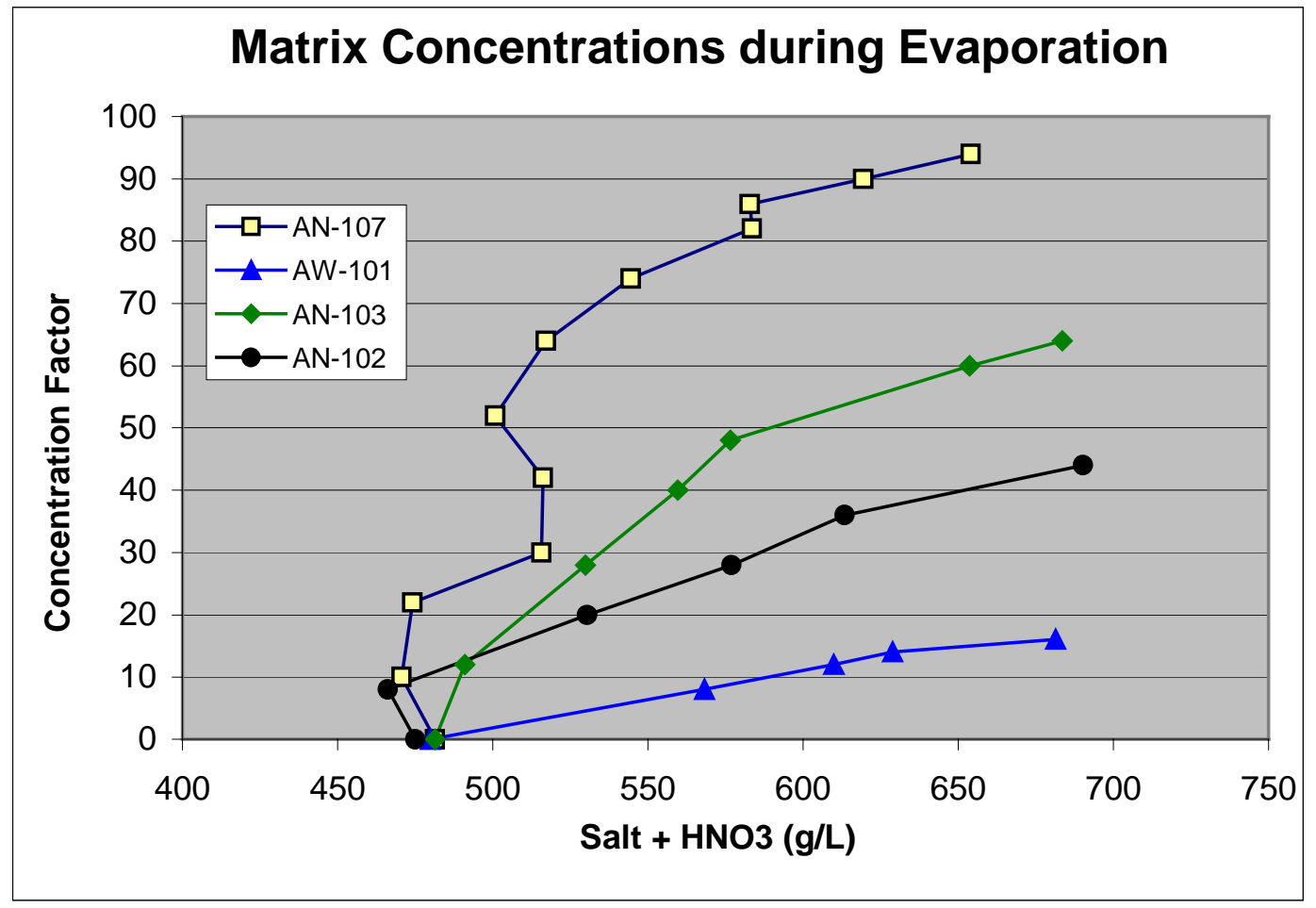




\section{WSRC-TR-2003- 00135, Rev. 0 \\ SRT-RPP-2003-00045}

Based on previous solubility and precipitation studies, ${ }^{8}$ it was expected that the only solids that would form upon precipitation were sodium nitrate solids. Therefore, no plan existed to sample and analyze solids. However, when the AN-103 experiment exhibited an evaporation profile that differed from the others, and because it contained a relatively large amount of calcium nitrate, a solid sample was taken and submitted for x-ray diffraction. The analysis showed only sodium nitrate solids from the AN-103 test. Based on this result and the earlier experiments, it can be reasonably assumed that all of the solids generated from these tests were sodium nitrate.

\subsection{EVAPORATION PROFILES - MODERATE- AND LOW-ACID TESTS}

\subsubsection{Evaporation Profiles}

The second stage of experimentation tested only one simulant (AN-102) under different starting and operating conditions. The objective of these tests was to assess the effects of 1) changing the starting acid concentration in the evaporator pot and 2) using atmospheric pressure instead of vacuum. As with the earlier tests, since the primary component in all four tests is $\mathrm{NaNO}_{3}$, the end point for each experiment is estimated using $\mathrm{NaNO}_{3}-\mathrm{HNO}_{3}$ solubility data. Greater attention was given to the manner in which nitric acid concentration changed throughout each test. This is represented in the $\mathrm{HNO}_{3}-\mathrm{NaNO}_{3}$ profile during evaporation

The $\mathrm{NaNO}_{3}-\mathrm{HNO}_{3}$ data for these tests is presented in Table 4-2. The acid concentration values in the are measured values using titration; sodium concentration data is calculated based on starting volume and total volumes of feed evaporated. Because the system contains only nitrate salts, $\mathrm{NaNO}_{3}$ is represented in the Table as $\mathrm{Na}^{+}$and $\mathrm{HNO}_{3}$ is represented as $\mathrm{H}^{+}$. The cells containing data with a gray background and bold text are those samples in which a precipitate was observed. It is important to note that the atmospheric pressure evaporation was not conducted to precipitation. The primary objective, to observe nitric acid behavior, was accomplished in the abbreviated test. The data of Table 4-2 has been plotted along with the experimental solubility curve for sodium nitrate (Figure 4-3).

Similar to Figure 4-1, it is worth noting that in Figure 4-3 precipitation occurred only in those samples that are above the $\mathrm{NaNO}_{3}-\mathrm{HNO}_{3}$ solubility curve. The data further support the conclusion that in those matrices where sodium nitrate is the dominant component, overall system saturation is accurately predicted using the $\mathrm{NaNO}_{3}-\mathrm{HNO}_{3}$ solubility profile.

More noteworthy is the behavior of the $4.0 \mathrm{M}$ and $5.25 \mathrm{M} \mathrm{HNO}_{3}$ tests under vacuum. Contrary to expectations, the acidity in the evaporator pot increased at the outset for both tests. Even though the feed was nominally $0.28 \mathrm{M}$ acid and the pot acidity was much higher, the initial condensate coming from the evaporator had less acidity than the feed. The trend of the acidity eventually turns to one where the acid in the evaporator pot decreases with time. It is unclear why the acidity trend changes when it does.

Also, both the $4.0 \mathrm{M}$ and $5.25 \mathrm{M} \mathrm{HNO}_{3}$ tests under vacuum demonstrate a tendency to concentrate to a lower total acid before precipitation occurs. While the $4.0 \mathrm{M}$ test showed a sharp increase in acidity toward the end of the test, it is important to recall that the evaporator pot was accidentally over-concentrated. Based on the behavior of the system prior to the excessive concentration, it is anticipated that its endpoint would have been comparable to that of the $5.25 \mathrm{M}$ test under vacuum.

While no definitive explanation for the observed behavior has been discovered, it is speculated that the waters of hydration associated with nitric acid may play a role. Figure 4-4 shows the different species observed in frozen nitric acid samples. It seems reasonable to speculate that the same species also exist in the liquid in equilibrium with the solids. The applicable trough between two different operating regions occurs at 12.5 mole percent $\mathrm{HNO}_{3}$ $\left(6.35 \mathrm{M} \mathrm{HNO}_{3}\right)$. The depth of the trough suggests that a fair amount of energy is required to transition from one region to the other.

For comparison, the high-acid tests $(7.5 \mathrm{M})$ start to the right of the trough while the low- $(4.0 \mathrm{M})$ and moderate$(5.25 \mathrm{M})$ acid tests start to the left of the trough. Furthermore, the moderate-acid experiment produces an acid

\footnotetext{
${ }^{8}$ R. A. Pierce and T. B. Edwards, “Cesium Eluate Evaporation Solubility and Physical Property Behavior," WSRCTR-2002-00273, dated June 11, 2002
} 


\section{WSRC-TR-2003- 00135, Rev. 0 \\ SRT-RPP-2003-00045}

concentration increase until 6.4M acid (the trough) before acidity begins to decrease. The low-acid test exhibited an initial trend that has acidity increasing at a faster rate than the moderate-acid test before some other effect dominates. The reason for why the endpoint for the low- and moderate-acid tests under vacuum may are lower than the high-acid test be attributable to differences in relative concentrations of nitric acid species (those to the right and left of the trough) in solution.

The result from the atmospheric pressure lends some support to this theory. The only difference between the two moderate-acid tests is that one occurs at 70 torr, with a boiling point of about $55^{\circ} \mathrm{C}$, while the other occurs at about 760 torr, with a boiling point of about $108^{\circ} \mathrm{C}$. The test at atmospheric pressure does not show the sharp increase in acidity. Rather, its acidity decreases steadily until it plateaus at $3.5 \mathrm{M} \mathrm{HNO}$. The primary difference with respect to the two liquids is boiling temperature. It is possible that the energy in the atmospheric pressure system is sufficient to overcome the trough and avoid concentrating the acid toward the trough of Figure 4-4, whereas the energy at 70 torr is insufficient to completely overcome the trough.

Table 4-2. AN-102 Semi-Batch Evaporation Data

\begin{tabular}{|c|c|c|c|c|c|c|c|c|c|c|c|}
\hline \multicolumn{3}{|c|}{$\begin{array}{l}\text { AN-102, } 70 \text { torr } \\
\text { High Acid }\end{array}$} & \multicolumn{3}{|c|}{$\begin{array}{l}\text { AN-102, } 70 \text { torr } \\
\text { Moderate Acid }\end{array}$} & \multicolumn{3}{|c|}{$\begin{array}{l}\text { AN-102, } 70 \text { torr } \\
\text { Low Acid }\end{array}$} & \multicolumn{3}{|c|}{$\begin{array}{l}\text { AN-102, } 760 \text { torr } \\
\text { Moderate Acid }\end{array}$} \\
\hline CF & $\mathrm{H}+(\mathrm{M})$ & $\mathrm{Na}+(\mathrm{M})$ & $\mathrm{CF}$ & $\mathrm{H}+(\mathrm{M})$ & $\mathrm{Na}+(\mathrm{M})$ & $\mathrm{CF}$ & $\mathrm{H}+(\mathrm{M})$ & $\mathrm{Na}+(\mathrm{M})$ & CF & $\mathrm{H}+(\mathrm{M})$ & $\mathrm{Na}+(\mathrm{M})$ \\
\hline 0 & 7.54 & 0.00 & 0 & 5.32 & 0.00 & 0 & 4 & 0.00 & 0 & 5.25 & 0.00 \\
\hline 4 & 7.06 & 0.26 & 4 & 5.51 & 0.26 & 4 & 4.28 & 0.26 & 4 & 5.39 & 0.26 \\
\hline 8 & 6.34 & 0.51 & 8 & 5.85 & 0.51 & 8 & 5.03 & 0.51 & 8 & 5.16 & 0.51 \\
\hline 12 & 6.09 & 0.77 & 12 & 6.02 & 0.77 & 12 & 4.97 & 0.77 & 12 & 4.7 & 0.77 \\
\hline 16 & 6.01 & 1.03 & 16 & 6.4 & 1.03 & 16 & 4.97 & 1.03 & 20 & 4.12 & 1.29 \\
\hline 20 & 5.77 & 1.29 & 20 & 6.05 & 1.29 & 20 & 4.93 & 1.29 & 28 & 3.43 & 1.80 \\
\hline 24 & 5.85 & 1.54 & 24 & 5.72 & 1.54 & 24 & 4.77 & 1.54 & 36 & 3.56 & 2.32 \\
\hline 28 & 5.45 & 1.80 & 28 & 5.4 & 1.80 & 32 & 4.54 & 2.06 & 44 & 3.59 & 2.83 \\
\hline 32 & 5.21 & 2.06 & 32 & 5.07 & 2.06 & 40 & 4.7 & 2.57 & & & \\
\hline 36 & 4.97 & 2.32 & 36 & 4.89 & 2.32 & 44 & 4.54 & 2.83 & & & \\
\hline 40 & 4.97 & 2.57 & 40 & 4.61 & 2.57 & 48 & 4.97 & 3.09 & & & \\
\hline 44 & 5.13 & 2.83 & 44 & 4.34 & 2.83 & & & & & & \\
\hline 48 & 5.05 & 3.09 & 48 & 4.31 & 3.09 & & & & & & \\
\hline & & & 52 & 4.38 & 3.35 & & & & & & \\
\hline & & & 56 & 4.64 & 3.60 & & & & & & \\
\hline
\end{tabular}

\subsubsection{AN-102 Condensate Data}

The condensate data from the experiments can be useful in confirming the observed acid behavior in the evaporator pot. The condensate data (Table 4-3) also exhibits a fair amount of fluctuation between samples. Because acidity of the $\mathrm{AN}-102$ feed concentration is $0.31 \mathrm{M}$ (by conductivity), it is expected that condensate acidity less than $0.31 \mathrm{M}$ would indicate an increasing evaporator pot acidity; condensate acidity near $0.31 \mathrm{M}$ would indicate that the evaporator pot acidity is relatively unchanged. In the early stages of the two moderate-acid tests and the low-acid test, the condensate acidity data confirm an acid increase in the evaporator pot. Furthermore, the latter stages of the low-acid and the moderate-acid (760 torr) tests confirm that the evaporator pot acidity is relatively constant. In general, the condensate behavior of Table 4-3 is consistent with the findings of Figure 4-3.

Condensate data for the high-acid tests using simulants for Tanks AW-101, AN-103, and AN-107 are included as Table 4-4. 
Figure 4-3. AN-102 Cs Eluate Semi-Batch Evaporation Behavior

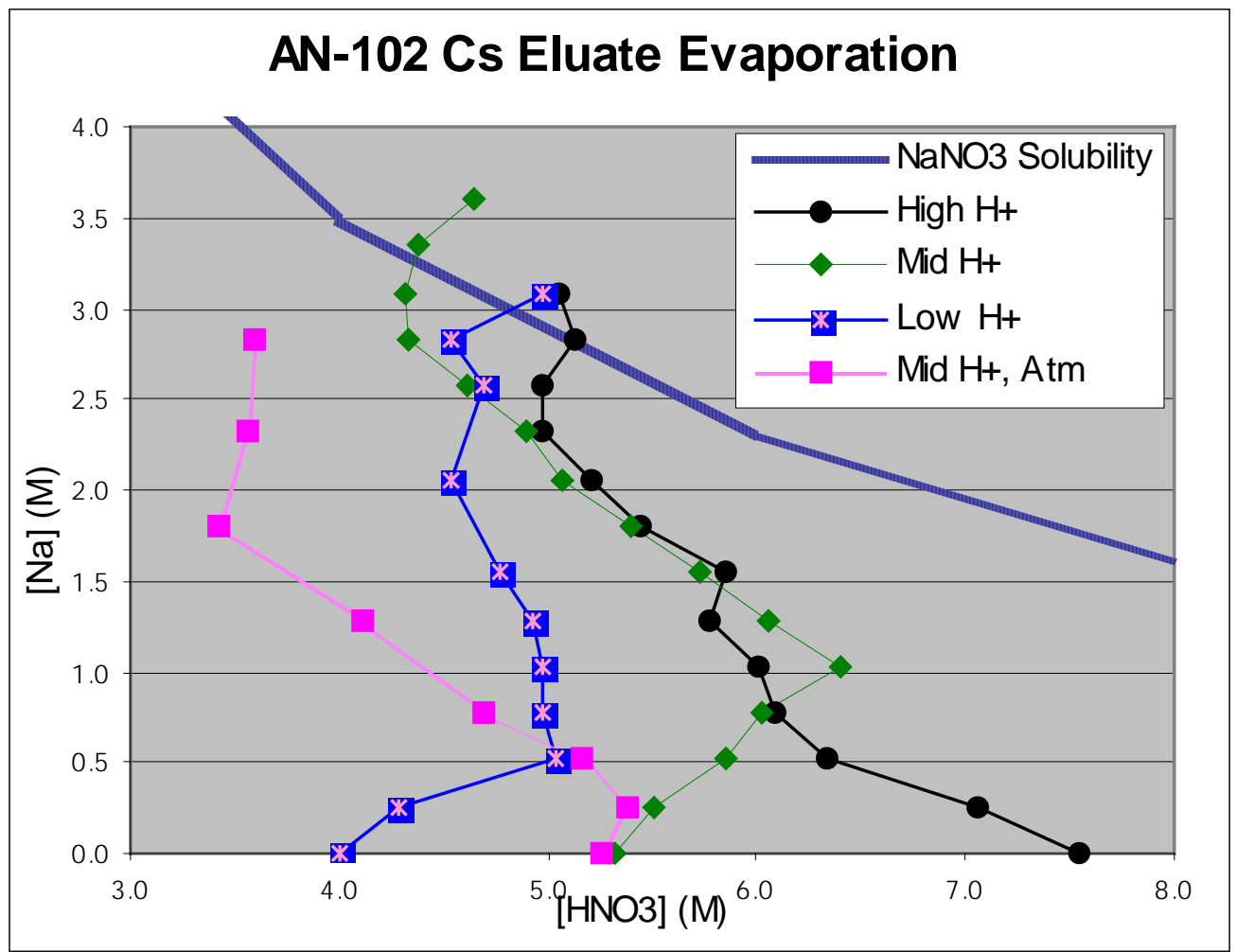

\subsection{PHYSICAL PROPERTIES - EVAPORATOR CONCENTRATE}

In addition to solubility data, physical property data was also collected. The physical properties measured included density, viscosity, and heat capacity. Very few samples were analyzed for viscosity or heat capacity because of the inability to take large samples throughout the experiment. Only one or two samples exist for each test - the final solution and maybe one sample near the saturation point.

\subsubsection{Density}

Density samples were collected throughout each test. The data, measured at $20^{\circ} \mathrm{C}$, is listed in Table $4-5$ and plotted in Figure 4-5 as a function of sodium concentration. The data trends linearly, but exhibits some fluctuation.

Because salt content increases linearly during the test, the variability is likely caused primarily by variability in the total acid data. It is expected that frequent sampling, which requires removing the vacuum from the system, can contribute to the fluctuations in acid concentration. 
Figure 4-4. Nitric Acid Hydration Species

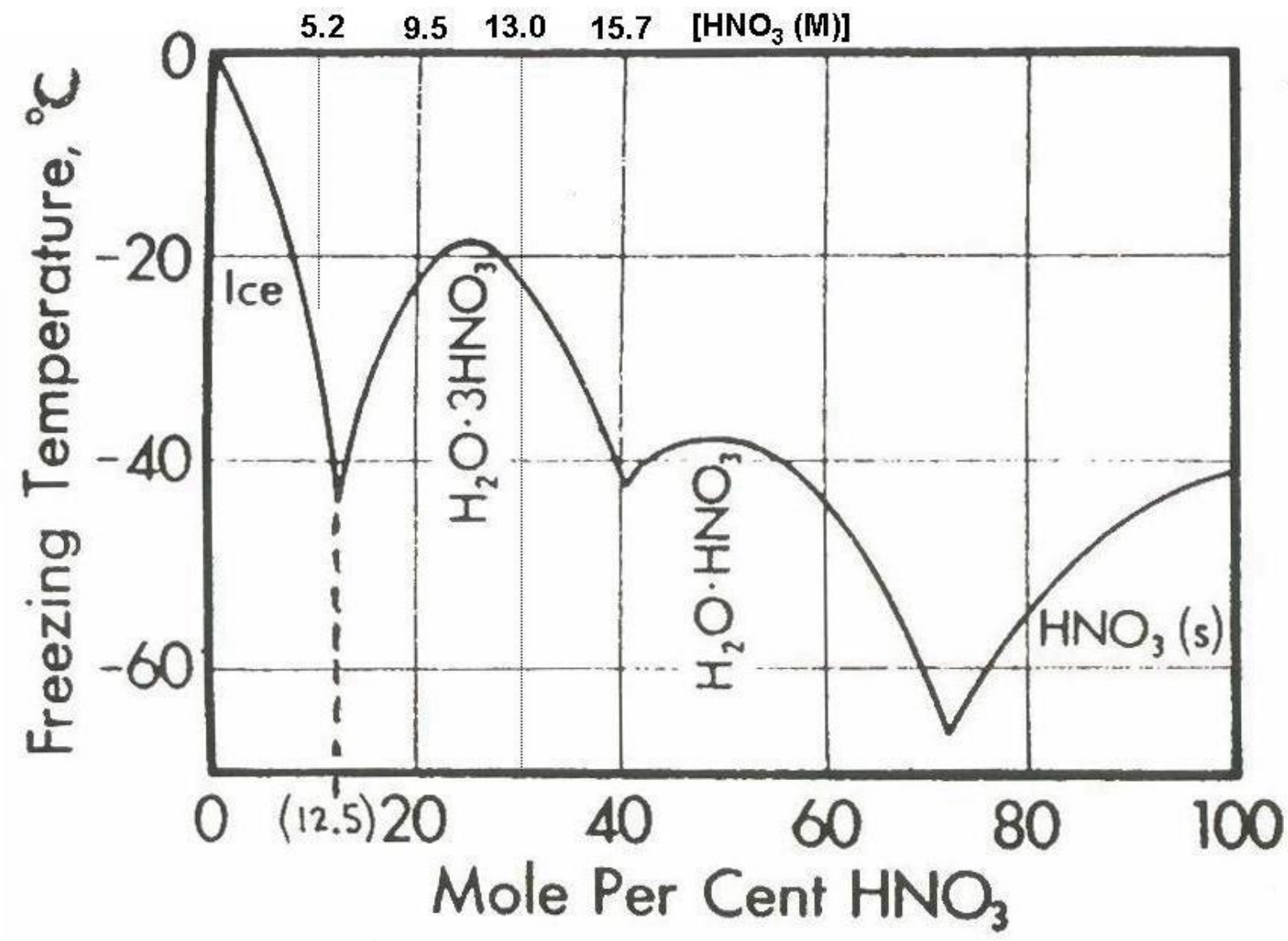

Table 4-3. AN-102 Condensate Data

\begin{tabular}{|c|c|c|c|c|c|c|c|c|c|c|c|}
\hline \multicolumn{3}{|c|}{$\begin{array}{l}\text { High Acid } \\
70 \text { torr }\end{array}$} & \multicolumn{3}{|c|}{$\begin{array}{l}\text { Moderate Acid } \\
70 \text { torr }\end{array}$} & \multicolumn{3}{|c|}{$\begin{array}{l}\text { Low Acid } \\
70 \text { torr }\end{array}$} & \multicolumn{3}{|c|}{$\begin{array}{l}\text { Moderate Acid } \\
760 \text { torr }\end{array}$} \\
\hline CF & $\begin{array}{c}\text { Pot } \\
H_{+}(\mathrm{M})\end{array}$ & $\begin{array}{c}\text { Condenser } \\
\mathrm{H}+(\mathrm{M})\end{array}$ & CF & $\begin{array}{c}\text { Pot } \\
\mathrm{H}+(\mathrm{M})\end{array}$ & $\begin{array}{c}\text { Condenser } \\
\mathrm{H}_{+}(\mathrm{M})\end{array}$ & $\mathrm{CF}$ & $\begin{array}{c}\text { Pot } \\
H_{+}(M)\end{array}$ & $\begin{array}{c}\text { Condenser } \\
H_{+}(\mathrm{M})\end{array}$ & $\mathrm{CF}$ & $\begin{array}{c}\text { Pot } \\
H_{+}(\mathrm{M})\end{array}$ & $\begin{array}{c}\text { Condenser } \\
\mathrm{H}_{+}(\mathrm{M})\end{array}$ \\
\hline$\overline{4}$ & 7.06 & $\overrightarrow{0.622}$ & 4 & 5.51 & 0.228 & $\overline{4}$ & 4.28 & 0.220 & $\overline{4}$ & 5.39 & 0.227 \\
\hline 8 & 6.34 & 0.411 & 8 & 5.85 & 0.209 & 8 & 5.03 & 0.278 & 8 & 5.16 & 0.373 \\
\hline 12 & 6.09 & 0.391 & 12 & 6.02 & 0.207 & 12 & 4.97 & 0.289 & 12 & 4.7 & 0.481 \\
\hline 16 & 6.01 & 0.366 & 16 & 6.40 & 0.339 & 16 & 4.97 & 0.341 & 20 & 4.12 & 0.424 \\
\hline 20 & 5.77 & 0.264 & 20 & 6.05 & 0.456 & 20 & 4.93 & 0.339 & 28 & 3.43 & 0.327 \\
\hline 24 & 5.85 & 0.402 & 24 & 5.72 & 0.455 & 24 & 4.77 & 0.317 & 36 & 3.56 & 0.330 \\
\hline 28 & 5.45 & 0.374 & 28 & 5.40 & 0.287 & 32 & 4.54 & 0.351 & 44 & 3.59 & 0.345 \\
\hline 32 & 5.21 & 0.313 & 32 & 5.07 & 0.480 & 40 & 4.70 & 0.305 & & & \\
\hline 36 & 4.97 & 0.400 & 36 & 4.89 & 0.410 & 44 & 4.54 & 0.341 & & & \\
\hline 40 & 4.97 & 0.340 & 40 & 4.61 & 0.358 & 48 & 4.97 & 0.406 & & & \\
\hline 44 & 5.13 & 0.398 & 44 & 4.34 & 0.425 & & & & & & \\
\hline 48 & 5.05 & 0.346 & 48 & 4.31 & 0.263 & & & & & & \\
\hline & & & 52 & 4.38 & 0.350 & & & & & & \\
\hline
\end{tabular}

Note: AN-102 feed measured to be $0.312 \mathrm{M}$ total acid 
WSRC-TR-2003- 00135, Rev. 0 SRT-RPP-2003-00045

Table 4-4. Multi-Tank Condensate Data

\begin{tabular}{|c|c|c|c|c|c|c|c|c|c|c|c|}
\hline \multicolumn{3}{|c|}{$\begin{array}{l}\text { AW-101 } \\
\text { High Acid, } 70 \text { torr }\end{array}$} & \multicolumn{3}{|c|}{$\begin{array}{l}\text { AN-102 } \\
\text { High Acid, } 70 \text { torr }\end{array}$} & \multicolumn{3}{|c|}{$\begin{array}{l}\text { AN-103 } \\
\text { High Acid, } 70 \text { torr }\end{array}$} & \multicolumn{3}{|c|}{$\begin{array}{l}\text { AN-107 } \\
\text { High Acid, } 70 \text { torr }\end{array}$} \\
\hline$\underline{\mathrm{CF}}$ & $\begin{array}{c}\text { Pot } \\
\underline{H+(M)}\end{array}$ & $\begin{array}{l}\text { Condenser } \\
\qquad \underline{H+(M)}\end{array}$ & $\underline{\mathrm{CF}}$ & $\begin{array}{c}\text { Pot } \\
\underline{H+(M)}\end{array}$ & $\begin{array}{c}\text { Condenser } \\
\underline{H+(M)}\end{array}$ & $\underline{\mathrm{CF}}$ & $\begin{array}{c}\text { Pot } \\
\underline{H}+(M)\end{array}$ & $\begin{array}{l}\text { Condenser } \\
\qquad \underline{H+(M)}\end{array}$ & $\underline{\mathrm{CF}}$ & $\begin{array}{c}\text { Pot } \\
\underline{H+(M)}\end{array}$ & $\begin{array}{c}\text { Condenser } \\
\qquad \underline{H+(M)}\end{array}$ \\
\hline$\overline{4}$ & 7.62 & $\overrightarrow{0.556}$ & $\overline{4}$ & 7.06 & 0.622 & 4 & & 0.365 & 4 & & 0.398 \\
\hline 8 & 6.29 & 0.686 & 8 & 6.34 & 0.411 & 8 & & 0.395 & 8 & & 0.425 \\
\hline 12 & 5.59 & 0.253 & 12 & 6.09 & 0.391 & 12 & 6.61 & 0.320 & 10 & 7.00 & \\
\hline 16 & 5.37 & 0.541 & 16 & 6.01 & 0.366 & 16 & & 0.156 & 12 & & 0.400 \\
\hline & & & 20 & 5.77 & 0.264 & 20 & & 0.494 & 16 & & 0.558 \\
\hline & & & 24 & 5.85 & 0.402 & 24 & & 0.560 & 20 & & 0.387 \\
\hline & & & 28 & 5.45 & 0.374 & 28 & 5.65 & 0.274 & 22 & 6.48 & 0.334 \\
\hline & & & 32 & 5.21 & 0.313 & 32 & & 0.350 & 26 & & 0.303 \\
\hline & & & 36 & 4.97 & 0.400 & 36 & & 0.287 & 30 & 6.76 & 0.426 \\
\hline & & & 40 & 4.97 & 0.340 & 40 & 4.94 & 0.289 & 34 & & 0.399 \\
\hline & & & 44 & 5.13 & 0.398 & 44 & & 0.257 & 38 & & 0.538 \\
\hline & & & 48 & 5.05 & 0.346 & 48 & 4.42 & 0.341 & 42 & 6.20 & 0.411 \\
\hline & & & & & & 52 & 4.58 & 0.236 & 46 & & 0.459 \\
\hline & & & & & & 56 & 4.46 & 0.338 & 50 & & 0.494 \\
\hline & & & & & & 60 & 4.46 & 0.252 & 52 & 5.48 & \\
\hline & & & & & & 64 & 4.54 & 0.248 & 54 & & 0.325 \\
\hline & & & & & & & & & 58 & & 0.511 \\
\hline & & & & & & & & & 62 & & 0.322 \\
\hline & & & & & & & & & 64 & 5.17 & 0.503 \\
\hline & & & & & & & & & 68 & & 0.272 \\
\hline & & & & & & & & & 72 & & 0.354 \\
\hline & & & & & & & & & 74 & 5.13 & \\
\hline & & & & & & & & & 76 & & 0.321 \\
\hline & & & & & & & & & 80 & & 0.312 \\
\hline & & & & & & & & & 82 & 5.37 & \\
\hline & & & & & & & & & 84 & & 0.483 \\
\hline & & & & & & & & & 86 & 5.17 & 0.464 \\
\hline & & & & & & & & & 90 & 5.56 & 0.203 \\
\hline & & & & & & & & & 94 & 5.92 & 0.335 \\
\hline
\end{tabular}




\subsubsection{Viscosity and Heat Capacity}

Heat capacity and viscosity data are reported to present the experimental results (Table 4-6). The viscosity data is plotted in Figure 4-6. The plot shows that the relative values for the viscosity data, as a function of temperature, are consistent. The data consistency lends confidence to the data quality. Furthermore, a comparison of the viscosity data for water with data listed by NIST shows good agreement. Experimental data measured $0.927 \mathrm{cP}$ at $23^{\circ} \mathrm{C}$ and $0.559 \mathrm{cP}$ at $50^{\circ} \mathrm{C}$ for deionized water compared to NIST values of $0.932 \mathrm{cP}$ at $23^{\circ} \mathrm{C}$ and $0.547 \mathrm{cP}$ at $50^{\circ} \mathrm{C}$.

Table 4-5. Summary of Experimental Density Data

\begin{tabular}{|c|c|c|}
\hline \multicolumn{3}{|c|}{ AW-101 Experimental Data } \\
\hline & & Total Salt \\
\hline$\underline{\mathrm{CF}}$ & $\begin{array}{l}\text { Density } \\
(\mathrm{g} / \mathrm{mL})\end{array}$ & $\begin{array}{l}+ \text { acid } \\
(\mathrm{g} / \mathrm{L})\end{array}$ \\
\hline 0 & $\overline{-----}$ & $\overline{479.9}$ \\
\hline 8 & 1.2599 & 568.2 \\
\hline 12 & 1.3217 & 609.9 \\
\hline 14 & 1.3133 & 628.8 \\
\hline 16 & 1.3477 & 681.3 \\
\hline \multicolumn{3}{|c|}{ AN-103 Experimental Data } \\
\hline & & Total Salt \\
\hline$\underline{\mathrm{CF}}$ & $\begin{array}{l}\text { Density } \\
(\mathrm{g} / \mathrm{mL})\end{array}$ & $\begin{array}{l}+ \text { acid } \\
(\mathrm{g} / \mathrm{L})\end{array}$ \\
\hline 0 & ---- & 481.4 \\
\hline 12 & 1.2530 & 491.0 \\
\hline 28 & 1.2978 & 529.9 \\
\hline 40 & 1.3225 & 559.7 \\
\hline 48 & 1.3140 & 576.6 \\
\hline 60 & 1.3722 & 653.6 \\
\hline 64 & 1.3829 & 683.5 \\
\hline
\end{tabular}

\begin{tabular}{|c|c|c|c|c|c|}
\hline \multicolumn{3}{|c|}{ AN-102 Experimental Data } & \multicolumn{3}{|c|}{ AN-107 Experimental Data } \\
\hline & & Total Salt & & & Total Salt \\
\hline $\mathrm{CF}$ & $\begin{array}{l}\text { Density } \\
(\mathrm{g} / \mathrm{mL})\end{array}$ & $\begin{array}{l}+ \text { acid } \\
(\mathrm{g} / \mathrm{L})\end{array}$ & $\underline{\mathrm{CF}}$ & $\begin{array}{l}\text { Density } \\
(\mathrm{g} / \mathrm{mL})\end{array}$ & $\begin{array}{c}+ \text { acid } \\
(\mathrm{g} / \mathrm{L})\end{array}$ \\
\hline 0 & ----- & 475.1 & 0 & ---- & 481.4 \\
\hline 8 & 1.2363 & 466.2 & 10 & 1.2465 & 470.7 \\
\hline 20 & 1.2664 & 530.4 & 22 & 1.2408 & 474.1 \\
\hline 28 & 1.2917 & 576.9 & 30 & 1.2681 & 515.6 \\
\hline 36 & 1.3041 & 613.4 & 42 & 1.2708 & 516.2 \\
\hline 44 & 1.3625 & 690.2 & 52 & 1.2723 & 500.8 \\
\hline & & & 64 & 1.2942 & 517.1 \\
\hline & & & 74 & 1.3028 & 544.5 \\
\hline & & & 82 & 1.2909 & 583.5 \\
\hline & & & 86 & 1.3063 & 582.9 \\
\hline & & & 90 & 1.3120 & 619.4 \\
\hline & & & 94 & 1.3372 & 654.1 \\
\hline
\end{tabular}

Figure 4-5. Cesium Eluate Evaporation Density

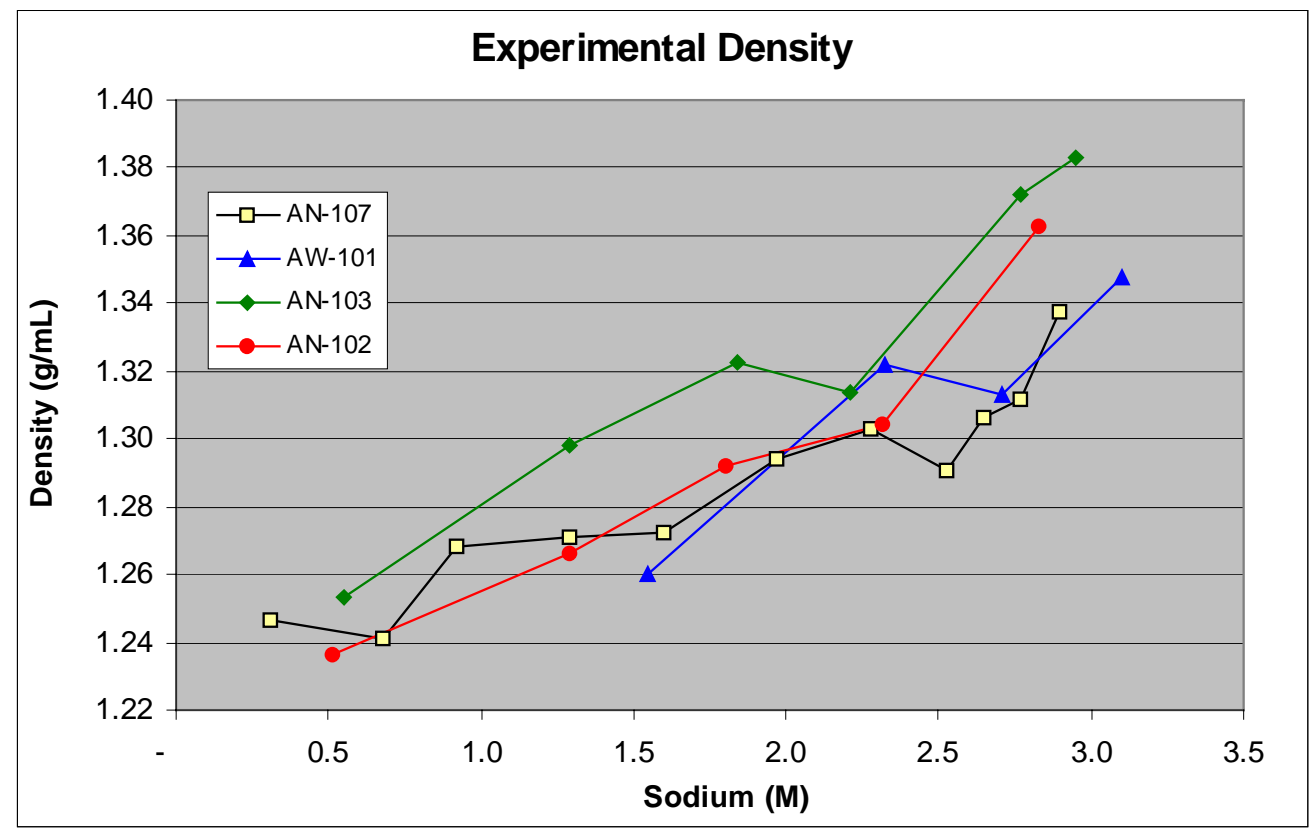


Heat capacity measurements (Table 4-5) also indicate a good level of reliability. Two samples from the same matrix (AW-101 and AN-107) are very close. Similarly, all of the samples, which are similar in total sodium and acid concentrations, exhibit comparable heat capacity values. Furthermore, a comparison of the viscosity data for water with data listed by NIST shows good agreement. Experimental data measured $0.993 \mathrm{cal} / \mathrm{g}-{ }^{\circ} \mathrm{C}$ at $50^{\circ} \mathrm{C}$ for deionized water compared to the NIST value of $0.999 \mathrm{cal} / \mathrm{g}-{ }^{\circ} \mathrm{C}$ at $50^{\circ} \mathrm{C}$.

Figure 4-6. Cesium Eluate Evaporation Viscosity

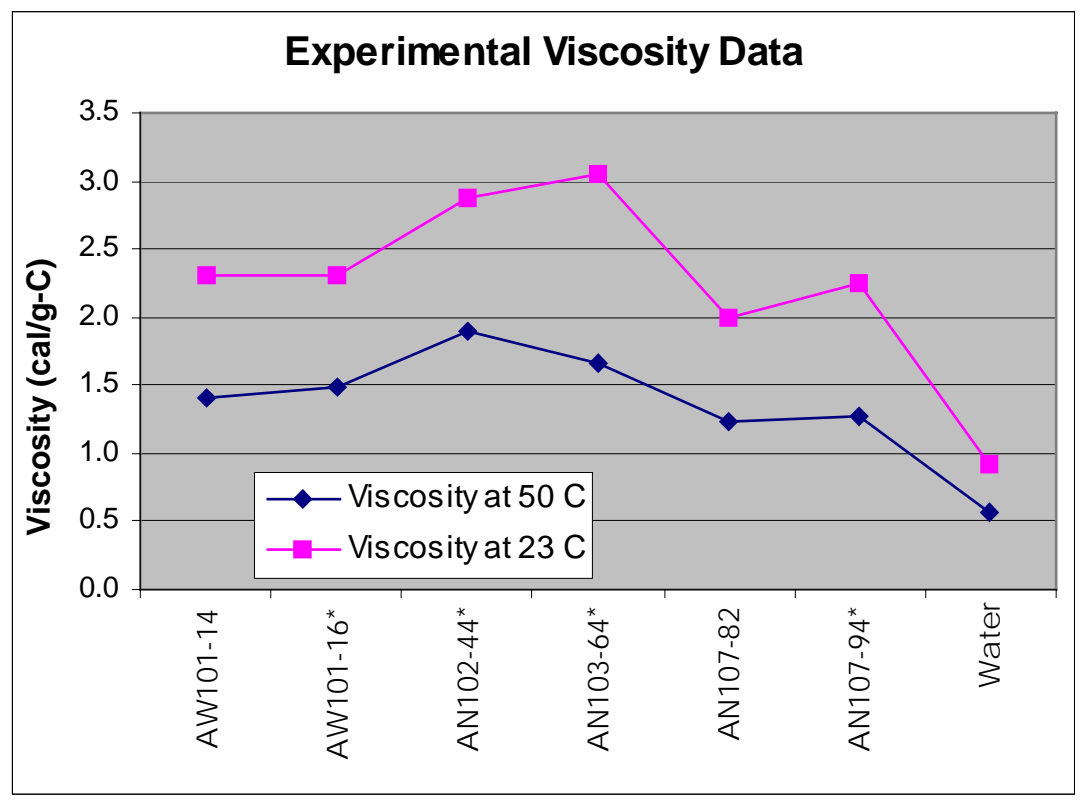

No attempt has been made to correlate salt+acid calculations to either viscosity or heat capacity data in a manner similar to density because the conclusions would be misleading. The density and salt+acid data of Table 4-5 are before precipitation for all samples. On the other hand, the data of Table 4-6 includes some samples prior to precipitation and others after precipitation occurs.

Table 4-6. Physical Property Data Comparisons

\begin{tabular}{|l|c|c|c|c|}
\hline Sample \# & $\begin{array}{c}\text { Temp } \\
(\mathrm{deg})\end{array}$ & $\begin{array}{c}\text { Density at Temp } \\
(\mathrm{g} / \mathrm{mL})\end{array}$ & $\begin{array}{c}\text { Viscosity } \\
(\mathrm{cP})\end{array}$ & $\begin{array}{c}\text { Heat Capacity } \\
(\mathrm{cal} / \mathrm{g}-\mathrm{C})\end{array}$ \\
\hline AW101-14 & 50 & 1.2886 & 1.406 & 0.683 \\
\hline AW101-16* & 50 & 1.3165 & 1.484 & 0.688 \\
\hline AN102-44* & 50 & 1.3281 & 1.894 & 0.671 \\
\hline AN103-64* & 50 & 1.3452 & 1.671 & 0.675 \\
\hline AN107-82 & 50 & 1.2909 & 1.231 & 0.695 \\
\hline AN107-94* & 50 & 1.2954 & 1.269 & 0.698 \\
\hline Water & 50 & 0.9880 & 0.559 & 0.993 \\
\hline & & & & \\
\hline AW101-14 & 23 & 1.3133 & 2.314 & --- \\
\hline AW101-16* & 23 & 1.3446 & 2.317 & --- \\
\hline AN102-44* & 23 & 1.3508 & 2.871 & --- \\
\hline AN103-64* & 23 & 1.3791 & 3.058 & --- \\
\hline AN107-82 & 23 & 1.3137 & 1.991 & --- \\
\hline AN107-94* & 23 & 1.3331 & 2.256 & --- \\
\hline Water & 23 & 0.9972 & 0.927 & --- \\
\hline
\end{tabular}

* Indicates Samples that have formed solids from precipitation. 


\subsection{RECOMMENDED SIMULANT FOR PLANT COMMISSIONING}

The testing of individual cesium eluate simulants in a semi-batch manner is the precursor to recommending a cesium eluate simulant for plant commissioning. The primary characteristics sought in plant-commissioning simulant are that the simulant:

1. follows the dominant evaporator precipitation chemistry;

2. is based on the eluate of an actual Hanford tank composistion;

3 . is based on an eluate composition that is well-characterized;

4. is based on an eluate composition that has been evaluated experimentally.

5. behaves in a manner representative of several tank compositions;

6. has the potential to precipitate cesium under adverse conditions;

7. requires an average concentration factor (40-60 volumes) to produce a precipitate;

The use of simulant that meets these selection criteria will increase confidence in the likelihood of success during plant commissioning. Of the compositions evaluated, the AZ-102 matrix presents itself as the preferred matrix for plant commissioning. The specific reasons for this selection are as follows:

1. Alkali nitrates dominate the AZ-102 composition. Sodium, potassium, and cesium nitrates comprise of $98.5 \mathrm{wt} \%$ of the nitrate salts. Therefore, its precipitation behavior follows the dominant precipitation chemistry associated with sodium nitrate. Also, the use of only sodium nitrate for certain tests can provide an excellent approximation of AZ-102 performance.

2. AZ-102 is an actual tank composition.

3. AZ-102 has been well characterized - it seems to be the best-characterized Hanford tank solution.

4. AZ-102 has been tested extensively with both actual tank samples and with pilot-scale testing. The only pilot-scale ion exchange eluate to be evaporated is AZ-102. The concentrate from those tests is undergoing additional experimentation.

5. Of the five compositions tested, four of them (except AN-103) precipitate at essentially the same $\mathrm{HNO}_{3}$ $\mathrm{NaNO}_{3}$ endpoint (see Figure 4.1). As a result, the performance of an AZ-102 matrix at higher or lower total anhydrous salt concentrations (see Table 3-1) will provide a good approximation for other tank compositions (AW-101, AN-102, AN-107).

6. AZ-102 has a high cesium content. It is the only simulant tested to repeatedly produce cesium nitrate as a second precipitate.

7. AZ-102 precipitates at a concentration factor between 40 and 50. This is preferable to those of AW-101 (concentration factor $=14)$ and $\mathrm{AN}-107($ concentration factor $=90)$.

A batch formulation for a test simulant is contained in Attachment 2. Chromium is present in relatively high concentrations $(59.3 \mathrm{mg} / \mathrm{L}$ in pilot plant eluate). It is possible to chromium with iron without measurably affecting the performance of the simulant. The reason is twofold. Chromium is a hazardous metal and ought to be used only if its solubility might affect overall system performance. Chromium nitrate is very soluble and therefore subject to replacement with a compound of similar molecular weight (iron) without impacting system solubility.

\subsection{CONCLUSIONS}

Of the five simulant compositions tested with the same starting acid concentration (7.5-7.6M), four evaporation profiles (AZ-102, AN-102, AN-107 and AW-101) are quite similar. These four evaporation profiles cross the $\mathrm{NaNO}_{3}-\mathrm{HNO}_{3}$ solubility curve at essentially the same point. The similarity of behavior is noteworthy considering the significant differences between the different test matrices in both salt and acid concentrations. The fifth matrix (AN-103) behaves similar to the others until the end. The divergence of AN-103 is likely due to the high Ca-to-Na ratio in the feed. 


\section{WSRC-TR-2003- 00135, Rev. 0 SRT-RPP-2003-00045}

It was also observed that evaporator pot acidity does not always change linearly during the evaporation. All five tests show linear depletion of nitric acid in the evaporator pot from the start of the test until 5.0-5.5M total acid. Afterwards, the total acid concentration remains relatively constant even though more feed is being continuously added and dilute acid is continuously removed.

When the starting acid concentration in the evaporator pot was reduced while running the AN-102 simulant, the evaporation profile changed. The acidity in the evaporator pot increased at the outset when the starting pot acidity was $4.0 \mathrm{M}$ and $5.25 \mathrm{M}$. Even though the feed was nominally $0.28 \mathrm{M}$ acid and the pot acidity was much higher, the initial condensate coming from the evaporator had less acidity than the feed. The trend of the acidity eventually turns to one where the acid in the evaporator pot decreases with time. It is unclear why the acidity trend changes when it does.

It was also observed that both the $4.0 \mathrm{M}$ and $5.25 \mathrm{M} \mathrm{HNO}_{3}$ tests under vacuum demonstrate a tendency to concentrate to a lower total acid (4.3-4.4M) before precipitation occurs. While no definitive explanation for the observed behavior has been discovered, it is speculated that the waters of hydration associated with nitric acid may play a role.

The result from the atmospheric pressure at 5.25M starting acid lends some support to this theory. The only difference between the two moderate-acid tests is that one occurs at 70 torr, with a boiling point of about $55^{\circ} \mathrm{C}$, while the other occurs at about 760 torr, with a boiling point of about $108^{\circ} \mathrm{C}$. The test at atmospheric pressure does not show the sharp increase in acidity. Rather, its acidity decreases steadily until it plateaus at $3.5 \mathrm{M} \mathrm{HNO}$. The primary difference with respect to the two liquids is boiling temperature. It can be reasonably postulated that the energy in the atmospheric pressure system (boiling point $=108^{\circ} \mathrm{C}$ ) is sufficient to overcome the transition between two different nitric acid hydration species and avoid concentrating. The energy at 70 torr (boiling point $=55^{\circ} \mathrm{C}$ ) is insufficient to completely overcome the transition between two different nitric acid hydration species.

In addition to solubility data, physical property data was also collected. The physical properties measured included density, viscosity, and heat capacity. Very few samples were analyzed for viscosity or heat capacity because of the inability to take large samples throughout the experiment. Density samples were collected throughout each test. The data trends linearly, but exhibits some fluctuation. Because salt content increases linearly during the test, the variability is likely caused primarily by variability in the total acid data. Frequent sampling, which requires removing the vacuum from the system, can contribute to the fluctuations in acid concentration.

The testing of individual cesium eluate simulants in a semi-batch manner is the precursor to recommending a cesium eluate simulant for plant commissioning. Although there are many candidate compositions, from actual tank data to experimental formulations, the preferred candidate should be a simulant of an actual tank composition. Such a selection will increase confidence in the likelihood of success during plant commissioning. In addition, the selected simulant should be a composition that 1) is well-characterized, 2) has been evaluated experimentally, 3) is easy to simulate, and 4) has the potential to precipitate cesium under adverse conditions. Of the compositions evaluated, the AZ-102 matrix presents itself as the preferred matrix for plant commissioning. 


\subsection{ATTACHMENTS}

ATTACHMENT 1. Comparison of Electrical Conductivity Data for Nitric Acid ${ }^{9}$

$\begin{array}{cc}\begin{array}{c}\text { LITERATURE VALUES } \\ \text { Weight \% } \\ \text { HNO3 } \\ \hline 2.0\end{array} & \begin{array}{c}\text { Conductivity } \\ \text { (mS/cm) }\end{array} \\ 4.0 & 100 \\ 6.2 & 195 \\ 10.0 & 312 \\ 12.4 & 440 \\ 24.8 & 542 \\ & 768\end{array}$

\section{EXPERIMENTAL DATA}

Weight \% Conductivity $\underline{\mathrm{HNO}} \quad \underline{(\mathrm{mS} / \mathrm{cm})}$

$1.82 \quad 86.8$

$3.39 \quad 167.7$

$4.86 \quad 238$

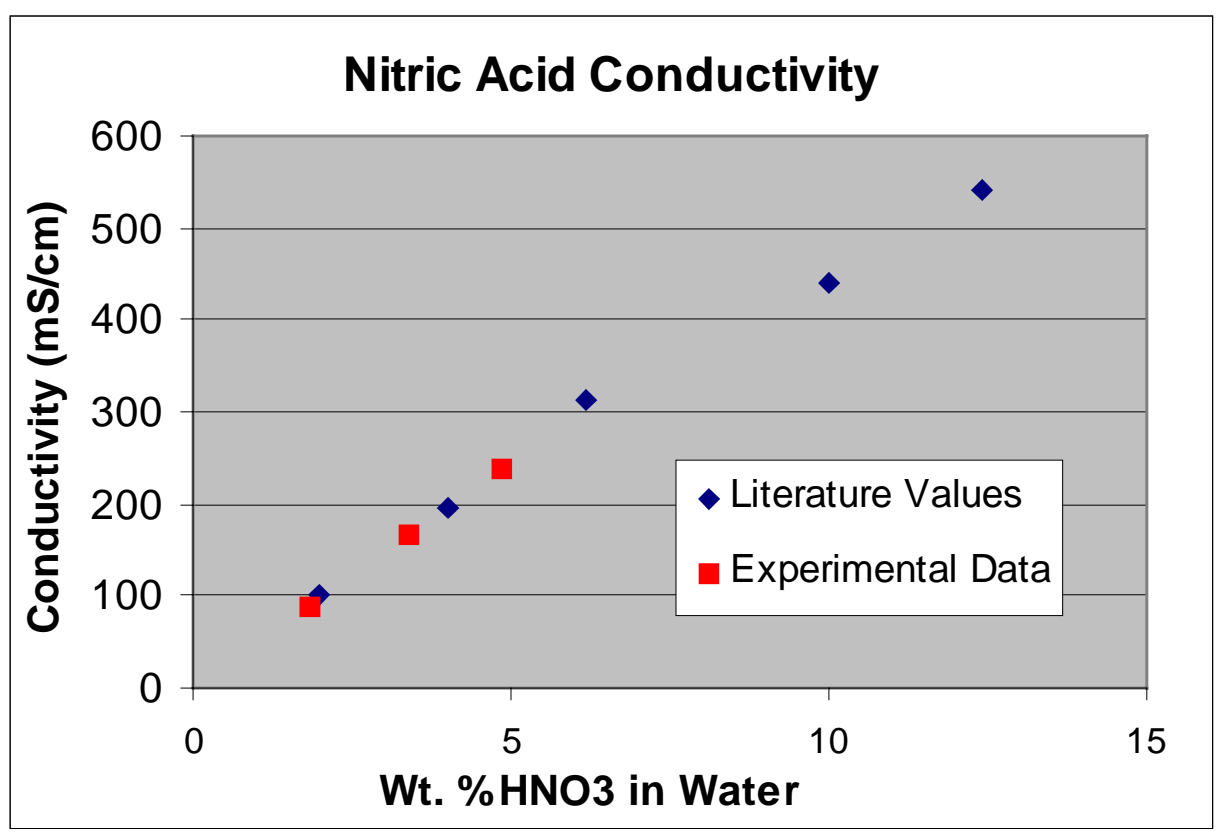

\footnotetext{
${ }^{9}$ Data from www.smartmeasurement.com (4/23/03) and from Yokagawa Systems conductivity plots (8/29/89)
} 
ATTACHMENT 2. Batch Sheet for Plant-Commissioning Simulant

\begin{tabular}{|c|c|c|c|}
\hline $\begin{array}{l}\text { Solid Compounds } \\
\text { To Add to Liquid } \\
\end{array}$ & $\begin{array}{l}\text { Hydrated } \\
\text { Salt FW }\end{array}$ & $\begin{array}{r}\text { Added } \\
\text { per liter }\end{array}$ & $\begin{array}{l}\text { Unit of } \\
\text { Measure }\end{array}$ \\
\hline $\mathrm{Na}_{2} \mathrm{SO}_{4}$ & 142.07 & 0.0555 & $G$ \\
\hline $\mathrm{NaNO}_{3}$ & 84.99 & 5.5432 & $\mathrm{G}$ \\
\hline $\mathrm{Na}_{2} \mathrm{C}_{2} \mathrm{O}_{4}$ & 134.00 & 0.0076 & $G$ \\
\hline $\mathrm{Al}\left(\mathrm{NO}_{3}\right)_{3}-9 \mathrm{H}_{2} \mathrm{O}$ & 375.13 & 0.0514 & $G$ \\
\hline $\mathrm{Ca}\left(\mathrm{NO}_{3}\right)_{2}-4 \mathrm{H}_{2} \mathrm{O}$ & 236.15 & 0.0383 & $G$ \\
\hline $\mathrm{Cr}\left(\mathrm{NO}_{3}\right)_{3}-9 \mathrm{H}_{2} \mathrm{O}$ & 400.18 & 0.4563 & $G$ \\
\hline $\mathrm{Cu}\left(\mathrm{NO}_{3}\right)_{2}-2.5 \mathrm{H}_{2} \mathrm{O}$ & 232.6 & 0.0105 & $g$ \\
\hline $\mathrm{Fe}\left(\mathrm{NO}_{3}\right)_{3}-9 \mathrm{H}_{2} \mathrm{O}$ & 404 & 0.0375 & $g$ \\
\hline $\mathrm{KNO}_{3}$ & 101.1 & 0.0667 & $g$ \\
\hline $\mathrm{CsNO}_{3}$ & 194.91 & 0.0235 & $\mathrm{~g}$ \\
\hline $70 \mathrm{wt} \% \mathrm{HNO}_{3}(15.9 \mathrm{M})$ & ---- & 32.70 & $\mathrm{~mL}$ \\
\hline Deionized Water & \multicolumn{3}{|c|}{ Balance of Volume to 1.0 liter } \\
\hline \multicolumn{3}{|c|}{ TARGET COMPOSITION AND PROPERTIES } & \\
\hline Analyte & Pilot Plant & Cation & \\
\hline (mg/L) & AZ-102 Eluate & MW & \\
\hline $\mathrm{Na}$ & 1520 & 22.99 & \\
\hline$\overline{A l}$ & 3.7 & 26.98 & \\
\hline $\mathrm{Ca}$ & 6.5 & 40.08 & \\
\hline $\operatorname{Cr}(\mathrm{III})$ & 59.3 & 52.01 & \\
\hline $\mathrm{Cu}(\mathrm{II})$ & 2.88 & 63.5 & \\
\hline $\mathrm{Fe}(\mathrm{III})$ & 5.18 & 55.85 & \\
\hline $\mathrm{K}$ & 25.8 & 39.1 & \\
\hline Cs & 16.0 & 132.9 & \\
\hline $\mathrm{SO}_{4}$ & 37.5 & 96.06 & \\
\hline $\mathrm{C}_{2} \mathrm{O}_{4}$ & 5.0 & 88.02 & \\
\hline $\mathrm{NO}_{3}$ & Balance of Cations & 62.01 & \\
\hline Total Acid as $\mathrm{HNO}_{3}$ & 0.52 & $\mathrm{~mol} /$ /iter & \\
\hline Density & 1.020 & $\mathrm{~g} / \mathrm{cc}$ & \\
\hline Viscosity & 0.90 & $\mathrm{cP}$ & \\
\hline
\end{tabular}

